\title{
CONTRIBUTIONS TO THE STUDY OF THE EARLY JURASSIC PETRIFIED FOREST OF HOLBAV AND CRISTIAN AREAS (BRAŞOV REGION, SOUTH CARPATHIANS, ROMANIA), $2^{\text {ndPART. }}$
}

\author{
Stănilă Iamandei ${ }^{1 *}$, Eugenia Iamandei ${ }^{1}$ \& Eugen Grădinaru ${ }^{2}$
}

Received: 1 July 2021 / Accepted: 9 September 2021 / Published online: 1 October 2021

\begin{abstract}
The present paper represents the second part of the palaeoxylotomical study on the "Grădinaru Collection" that is housed by the National Museum of Geology, Bucharest. By the study of a new material collected from the Getic domain of the South Carpathians, Romania, the following taxa were identified and discussed in detail: Protocupressinoxylon dragastanii, Protojuniperoxylon holbavicum (sp. nov.), Brachyoxylon holbavicum, B. cristianicum, Palaeoginkgoxylon sp., Bucklandia sp. A, and Bucklandia sp. B. All the studied specimens suggest to a tropical Early Jurassic petrified forest. Thus, the new data have not only palaeobotanical importance, but they also contribute to the palaeobiogeographic, palaeoecologic and palaeoclimatologic knowledge of the Mesophytic.
\end{abstract}

Keywords: Early Jurassic Flora, Petrified Forest, Gymnosperms, new taxa.

\section{INTRODUCTION}

The present paper continues the study of the "Grădinaru Collection" that is housed by the National Museum of Geology, Bucharest, which is affiliated to the Geological Institute of Romania. Detailed information on the geological setting and stratigraphic data regarding the newly described material have been provided in the first part of our study, devoted to the petrified woods found in the Lower Jurassic coaly deposits from the Holbav and Cristian areas, which are located in the easternmost part of the Getic domain, in South Carpathians (see Iamandei et al., 2018).

In addition to the older material collected by EG more than 50 years ago, new material collected in 2008 from the Holbav area, during fieldwork by the authors, is studied here. The age of the coaly deposits in the Holbav area is Hettangian to early Toarcian, documented by palynological dating done by Antonescu (1973) and Antonescu (in Săndulescu et al., 1984), and also by Toarcian ammonoids found by EG in the overlying marine deposits (see Iamandei et al., 2018). On the contrary, in the Cristian area the coaly deposits are dated as HettangianSinemurian, with the first marine transgression during the Pliensbachian, as indicated by a diverse and abundant fauna of bivalves, belemnites and ammonoids (see Iamandei et al., 2018).

Several Early Jurassic lignotaxa have been described in the first part of our study (Iamandei et al., 2018), as follows: Agathoxylon holbavicum Iamandei, Iamandei and Grădinaru, Brachyoxylon holbavicum Iamandei, Iamandei and Grădinaru, Brachyoxylon cristianicum Iamandei, Iamandei and Grădinaru, Protophyllocladoxylon holbavicum Iamandei, Iamandei and Grădinaru and Palaeoginkgoxylon sp. The present palaeoxylotomical study represents an advance in the study of Early Jurassic petrified woods from the easternmost part of the Getic domain in the South Carpathians. Alongside already described lignotaxa, such as Brachyoxylon holbavicum, B. cristianicum, and Palaeoginkgoxylon sp. (in Iamandei et al., 2018), some new Early Jurassic lignotaxa are described here, as follows: Protocupressinoxylon dragastanii Iamandei and Iamandei 2000, Protojuniperoxylon holbavicum sp. nov., Bucklandia sp. A and Bucklandia sp. B.

\section{MATERIAL AND METHODS}

The studied fossil wood material was collected in the mid-section of the Maiului brook (coordinates: 45 $39^{\prime} 12.74^{\prime \prime} \mathrm{N} ; 25^{\circ} 22^{\prime} 51.02^{\prime \prime} \mathrm{E}$, elev. $776 \mathrm{~m}$ ), which is a tributary of the Holbav valley (see Fig. 2 in Iamandei et al. 2018), coming from the lower part of the effusive pyroclastic sequence of the Lower Jurassic deposits of the Holbav area.

The fossil wood material is represented by fragments of petrified trunks, sometimes partially charcoalified and subsequently silicified, being encased in volcanic lahar deposits. The original dimensions of the petrified trunk fragments are variable, from decimetric to metric.

The samples of petrified wood were firstly macroscopically studied and the directions of standard oriented sections: transverse, tangential and radial, were carefully marked. Then, slabs were cut and thin sections of petrographic type were made in the specialized laboratory of the Geological Institute of Romania, in Bucharest. The mounting of lamella was replaced by the application of a transparent lacquer pellicle (even with nail-polish).

The sections have been studied under a microscope with transmitted light (NIKON - Eclipse E400), and micropho-

\footnotetext{
${ }^{1}$ Geological Institute of Romania, 1st, Caransebeş Street, 012271 - Bucharest, Romania. iamandei@gmail.com

${ }^{2}$ University of Bucharest, Department of Geology, $1^{\text {st }}$, Bălcescu Nicolae Blvd., 010041, Bucharest, Romania. egradinaru@gmail.com

* Corresponding author
} 
tos of structural details were taken with a digital camera "EverFocus". Then, for each specimen, plates with microphotos were compiled using "PaintShopPro" program, combined with "StarOffice5.2-Presentation".

During the microscopic study, description of the xylotomical details with possible taxonomic value was done, for every specimen, in all the three standard orientated sections.

In the section of "Affinities and discussions" we compare our studied structures with published xylotomically described fossil forms, in order to identify the studied fossil wood as a known taxon, or a new taxon.

The xylotomic description generally followed the nomenclatural code for gymnosperm woods of IAWA Committee (2004) and Ruffinatto et al. (2015) and the genera assignment of Philippe and Bamford (2008) and also, the suprageneric taxonomy of Gymnosperms of Christenhusz et al. (2011) and Lu et al. (2014).

\section{SYSTEMATICS}

Gymnosperms

Division Pinophyta Cronquist, Takhtajan and Zimmermann ex Reveal, 1996

Order Cupressales Link, 1829

Family Hirmeriellaceae Harris, 1979

Genus Protocupressinoxylon Eckhold 1923, nom. cons. prop., (Bodnar, 2017)

Protocupressinoxylon dragastanii Iamandei and Iamandei, 2000

Fig. 1, a-i.

\section{Material}

The studied material is represented by 14 samples of silicified wood collected from the Holbav area. All studied samples are fragments of trunk or thick-branches, of decimetric size, dark to black color and by magnifying glass or even by naked eye, the regular fibrous structure without vessels suggesting a conifer wood. The described specimens attributed to this taxon have very similar details and have the following field-numbers within the "Grădinaru Collection": 1074, 1077, 1082, 1084, 1086, 1088, 1092, 1097, 1098, 1099, 1100, 1104, 1106, 1109 and are stored at the National Museum of Geology, in Bucharest, under the inventory numbers: 27691, 27692, 27693, 27694, 27695, 27696, 27697, 27698, 27699, 27700, 27701, 27702, 277203, 27720.

\section{Microscopic description}

Growth rings - in the studied samples represent secondary xylem, which is tracheidoxylic. Thus, in cross-section they appear more or less well developed, sometimes wide with more than 60 cells, showing a fairly abrupt or gradual transition from early- to late-wood and distinct boundaries of the growth-rings. Normal or traumatic axial resin canals absent.

Tracheids - in cross-section appear large and with relatively thin walls in the early-wood, having quasi- polygonal cross-section (4-5 sides), and are sometimes deformed by compression. They have radial/tangential diameters of 30-60(70) / 25-60(70) $\mu \mathrm{m}$ and the wall thickness of 4-7 $\mu \mathrm{m}$ double wall. Where gradual size transition is present, a well-developed transitional wood is visible, with tracheids gradually diminishing their section and tracheidal wall becoming progressively thicker, until the final 3-5 rows of the late-wood, which consist of smaller radially flattened cells (with $\mathrm{r} / \mathrm{tg}$ diameters of 20$25 / 10-20 \mu \mathrm{m})$ and thicker walled, of 8-10 $\mu \mathrm{m}$ across the double-wall, marking the growth-ring boundary. Between two successive rays, 1-9 radial rows of tracheids can be counted. Sometimes, radial rows of smaller-sized tracheids are intermingled. The density is between 750-1216 tracheids $/ \mathrm{mm}^{2}$. In longitudinal view, tracheids have on the radial walls 1-2-seriate pits, sometimes contiguous, and of mixed type, because when are biseriate the pits are often alternately arranged. Sometimes crassulae are present. The pits are of abietinean type, have 10-12 $\mu \mathrm{m}$ diameter and round to oval apertures, of 5-6 $\mu \mathrm{m}$. No details about torus. On the tangential walls, pits are usually absent, or rarely present, as poorly preserved, uniseriate, small round pits, of 5-6 $\mu \mathrm{m}$ in diameter, with small round to oval aperture. Inside the tracheids, organic deposits are sometimes present as dark remains. Average tracheid length is difficult to measure. Helical thickenings on tracheids are absent.

Axial parenchyma - in the cross sections is usually absent or rarely present, as dispersed thin-walled cells with dark content. In longitudinal view it appears as rows of rectangular cells, with the horizontal wall thin and smooth, rarely feebly nodular and with some dark remains inside.

Rays - usually appear thin in cross section while in tangential sections appear exclusively uniseriate, sometimes with some biseriate storeys, having up to 15 cells in height, sometimes more. Their density is 6-9 rays per tangential millimeter. In radial view the rays show homocellular aspect, with parenchymal cells all procumbent, 18-20 $\mu \mathrm{m}$ tall, marginals slightly taller, of 25-30 $\mu \mathrm{m}$. The horizontal ray-cell walls are smooth or slightly rough and usually pitted, and are relatively thin (2-3.5 $\mu \mathrm{m}$ double wall); the tangential end-walls are relatively thick, of 1.5$2 \mu \mathrm{m}$ the simple wall, smooth or slightly nodular, but usually poorly preserved. The indentures are missing or difficult to notice. Spiral thickenings were not observed, most probably are absent. The cross-field pitting is of cupressoid type, showing 1-2(4-5) pits, in 1-2 rows horizontally arranged, and sometimes irregular or even to slightly alternate aspect. The pits are oculipores of cupressoid type, $8-10 \mu \mathrm{m}$ in diameter, with slit-like or lenslike apertures of $2-5 \mu \mathrm{m}$. Sometimes cross-field pitting is difficult to observe, due to poor preservation or to the presence of organic content.

Radial or axial resin canals - are absent.

Mineral inclusions - usually are not present. 

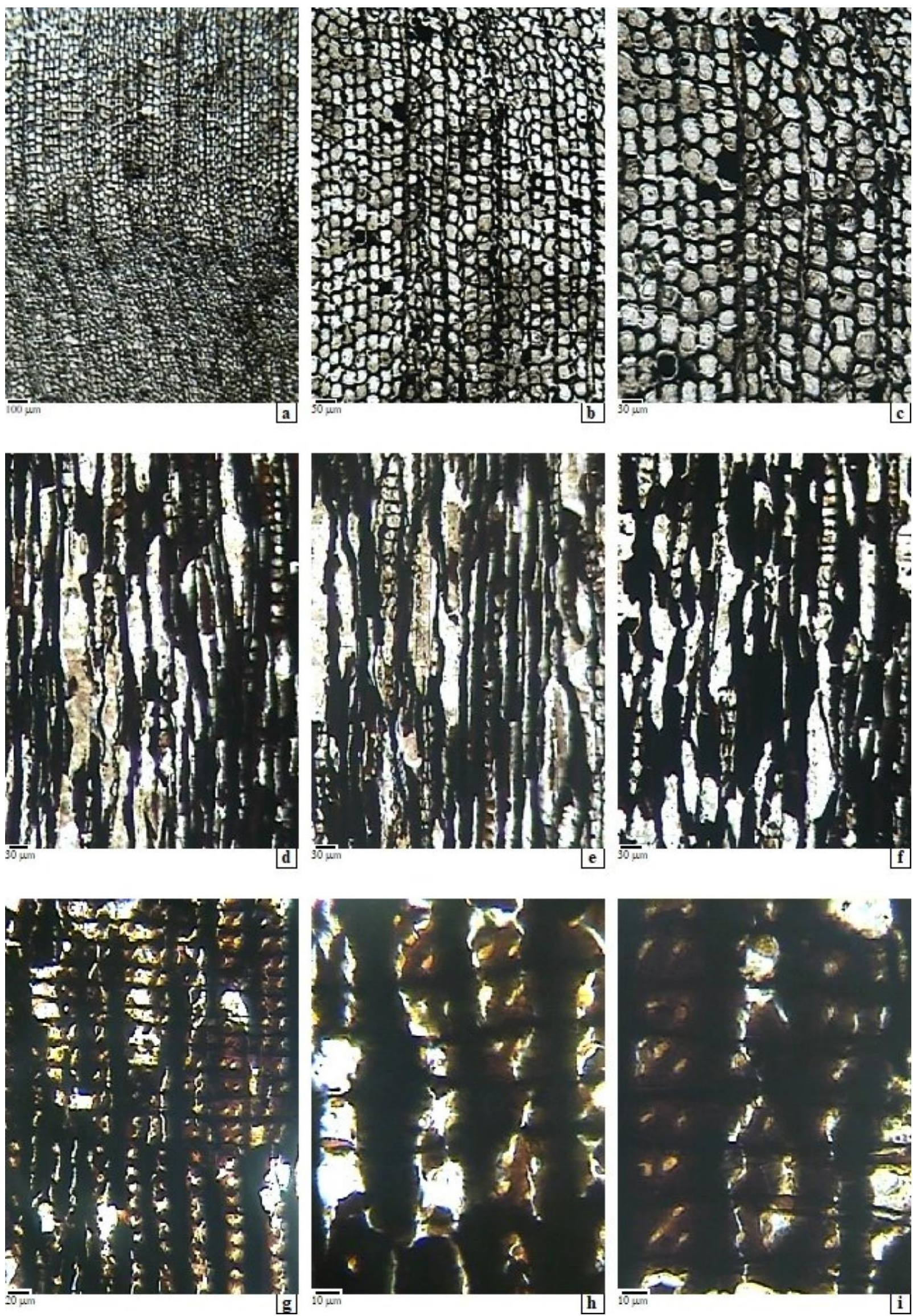

Fig. 1 Protocupressinoxylon dragastanii Iamandei and Iamandei, 2000 (inventory no. 27699).

a-c: Cross section - tracheids polygonal with rounded corners, linear rays and diffuse parenchyma; d-f: Tangential section uniseriate rays with polygonal ray-cells, sometimes with biseriate storeys; g-i: Radial section - radial pitting on tracheids 1-2 seriate, of mixed-type; when biseriate, pits are alternate (g, i); cross-fields with 1-2(4) cupressoid pits, when more - are slightly irregular or alternate, in two superposed rows $(\mathrm{g}, \mathrm{h})$. 


\section{Affinities and discussion}

The xylotomy of the here studied 14 specimens is definitely pycnoxylic and homoxylic (or tracheidoxylic sensu Creber, 1972), having tracheids with radial pitting of mixed type, no resin canals, little or no parenchyma, exclusively uniseriate rays and cross-fields with 1-2(4-5) cupressoid pits with slit-like inclined apertures, arranged in one or two horizontal rows, which are slightly irregularly to even alternately arranged; all these characters are evidence of a typical cupressaceous structure. Such details as: radial pitting on tracheids of mixed type, cupressoid pits in cross-fields, to fairly araucarioid arrangement, axial parenchyma showing few and radial pitting of tracheids of mixed type in a Mesozoic wood structure indicate a wood-type from "Cheirolepidiaceae family", as defined by Alvin et al. (1981) and Alvin (1982).

The synthetic description of all the studied specimens was compared with the diagnoses of Mesozoic genera with cupressoid oculipores in the cross-fields as described by Phillips (1941), Kräusel (1949), Vogellehner (1967, 1968), Müller Stoll and Schultze-Motel (1989), Philippe (1995, 2002), Bodnar (2017), and it appears that our material is mostly consistent, at generic level, with Protocupressinoxylon wood-type. In fact, the Mesozoic conifers were grouped, a long time ago, based on anatomical features, in the "Protopinaceae family" (Krausel, 1917 This family name was noted by Bamford et al. (2016) as having a dubious taxonomic status, and they recommended its abandon.

However, the name Cheirolepidiaceae, attributed to Turutanova-Ketova (see Fossil works - online), is not a valid name, as remarked by Doweld (2020), who considered an alternative name as being more correct for the Mesozoic gymnosperms characterized by pollen of Classopollistype. Thus, he applied the valid family name Hirmeriellaceae Harris, 1979 - and proposed this family name "for conservation against Cheirolepidiaceae", the latter being considered as "inadmissible, being based on the illegitimate later homonym Cheirolepis Schimper, and thus, itself illegitimate" (see Doweld, 2020).

This genus name, Protocupressinoxylon, was established by Eckhold (1922, pp. 490-491), to designate Mesozoic fossil conifer wood-types described like this: "wood with annual rings more or less distinct, tracheid pitting in various transitional arrangements, both horizontal and end walls of ray parenchyma cells smooth, resin canals absent, axial parenchyma occasionally present, cross-field pits cupressoid", but not specifying their number and arrangement.

Initially, Eckhold (1922) included seven species in the protologue: Protocupressinoxylon cupressoides, $P$. jurassicum, $P$. potomacense, $P$. eboracense, P. koettlitzi, $P$. vectense and $P$. mesozoicum, but without designation of a clear generotype. Only later, Andrews (1955) designated Protocupressinoxylon cupressoides (Holden) Eckhold, 1922 (not 1923, see Jogmans and Dijkstra, 1974, p. 794) as the species-type for that generic name. However, the species Protocupressinoxylon eboracense which was initially assigned as type-species of the Protobrachyoxylon genus (Holden, 1913) was included by Eckhold (1921) along with other species in the protologue of Protocupressinoxylon genus. But the original material seems to be lost, and the analysis of Holden's description and figuration suggest either identity with Protocupressinoxylon Eckhold, 1921 or with Brachyoxylon Hollick and Jeffrey, 1909 (see Bamford and Philippe 2001, Philippe, 2002).

Recently, Bodnar (2017) proposed the genus name Protocupressinoxylon to be conserved, together with a proposed generotype - P. malayense Roggeveen, 1932. Also, she proposed the necessity of a systematic revision of several described taxa, since abnormal details were described for some species of Kräusel (1949), like resin ducts in Protocupressinoxylon potomacense, $P$. solmsi, $P$. vectense, $P$. luccombense, or multiseriate rays, like in $P$. weidlingense (in Kräusel, 1949, pp. 183-185).

For this genus many species of fossil wood from all over the world ranging from Permian to Cretaceous have been described, especially after Kräusel (1949), who admited it as valid genus, and he even has described two species: $P$. dockumense (Torrey) Kräusel and P. coromandelinum (Sahni) Kräusel.

Later, new European species were described, as for example: Protocupressinoxylon catenatum Schultze-Motel 1960 (see also Iamandei and Iamandei, 2001), P. liasinum Schultze-Motel 1960, P. leonardianum (Charrier) Vogellehner 1968, P. rhaeticum Vogellehner 1968, $P$. munense Shilkina and Blokhina (in Blokhina, 1975), $P$. purbeckensis Francis 1983, P. carentanensis Barale (in Philippe, 1995).

Also, Iamandei and Iamandei $(2000,2005)$ have described an Early Cretaceous species from Dobrogea, Romania: Protocupressinoxylon dragastanii Iamandei et Iamandei, which has radial pitting uni- to biseriate, opposite or alternate, no parenchyma, rays of mid tall, uniseriate or partially biseriate and cross fields of cupressoid type, sometimes with an araucarioid tendency (i.e. alternate pits).

More recently, Correa et al. (2018) studying an abundant population of wood remains (58 permineralized trunks) from Argentina, described a new species as Protocupressinoxylon carrizalense, and made a comparative table of 32 species. They observed that only 24 from them fit the generic diagnosis, but eight species (i.e. Protocupressinoxylon alternans, P. cenomanicum, P. mesozoicum, $P$. luccombense, $P$. jurassicum, $P$. koetlizi, P. potomacense and $P$. vectense) present cross-fields pits that are different from the cupressoid type: either not bordered, or typical taxodioid (see Correa et al., 2018).

Since the specific details inside the genus Protocupressinoxylon are very similar, it is very difficult to discriminate between them, but through comparative study of their descriptions, and using also the comparative table from Correa et al. (2018), we tried to identify our material, which present these clear xylotomical features: tra- 
cheidoxylic secondary wood, having radial pitting 1-2 seriate, of mixed type on tracheids, few parenchyma or absent and uniseriate rays with cross-fields with 1-2(4-5) cupressoid pits per field, spaced arranged in 1-2 horizontal rows when more, to irregular, or to slightly alternate. These xylotomical details are very similar with those described by Iamandei and Iamandei (2000 and 2005) for the species Protocupressinoxylon dragastanii from the Early Cretaceous of South Dobrogea, Romania.

Thus, based on the above discussion, we attribute all the 14 studied specimens to the species Protocupressinoxylon dragastanii Iamandei and Iamandei, 2000, as another Mesozoic European taxon.

\section{Genus Protojuniperoxylon Eckhold, 1922 \\ Protojuniperoxylon holbavicum sp. nov.} Fig. 2, a-j.

\section{Material}

The studied material is represented by 7 samples of silicified wood, collected from the Holbav area, on Maiului brook. All studied samples are fragments of trunk or thick branches, of decimetric size, dark to black color. Viewing through a hand lens, or even by naked eye, it is possible to see the regular fibrous structure without vessels, which indicate a conifer wood. The specimens attributed to this species have very similar details and have the following field numbers within the "Grădinaru Collection": 1078, $1083,1085,1087,1091,1095,1110$ - and are stored at the National Museum of Geology, in Bucharest, under the inventory numbers: 27704, 27705, 27706, 27707, 27708, $27709,27710$.

\section{Microscopic description}

Growth rings - well developed in the studied samples, representing the secondary xylem which is tracheidoxylic, showing a fairly gradual transition but sometimes abrupt, from early- to late-wood, and has distinct growth ring boundaries. Normal or traumatic axial resin canals are absent.

Tracheids - in cross section appear quasi-polygonal, usually quadrangular, and with moderately thick walls in the early-wood. They have radial / tangential diameters of 25-60 / 25-55 $\mu \mathrm{m}$ in the early-wood and wall thickness of 3-7 $\mu \mathrm{m}$ double wall. When gradual transition is present, the tracheids gradually diminish in section and usually the tracheidal wall in the late-wood becomes slightly thicker, of 7-9 $\mu \mathrm{m}$ in the final 3-8 rows of smaller sized and radially flattened cells, with $\mathrm{r} / \mathrm{tg}$ diameters of 10-25 / 20-25 $\mu \mathrm{m}$, marking the growth-ring boundary. Between two successive rays, 2-12 radial rows of tracheids can be counted. The density ranges $750-1216$ tracheids $/ \mathrm{mm}^{2}$. Longitudinally, the tracheids have, on the radial walls, uniseriate pits, often with biseriate portions, often contiguous, or biseriate of mixed type, sometimes separated by crassulae. The pits are of abietinean type, have 14-21 $\mu \mathrm{m}$ in diameter and round apertures of 4-5 $\mu \mathrm{m}$. Details on torus not observed. On the tangential walls, pits are usual- ly absent. Organic deposits - absent. Average tracheids length difficult to measure. Helical thickenings usually absent, or rarely appear.

Axial parenchyma - in the cross sections is absent, or rarely present as dispersed thin-walled cells with dark content. In longitudinal view, the parenchyma appears as vertical rows of rectangular cells, with the horizontal wall thin and smooth or feebly nodular and with some dark remains inside.

Rays - usually thin in cross section, appear in tangential section as uniseriate, but sometimes with some biseriate storeys, or even as 2-3-seriate rays. The ray height varies from 2-32 to up to 56 cells (average height - 16 cells). The ray cells appear ovoid-rectangular, with $26-39 \mu \mathrm{m}$ in height and 23-30 $\mu \mathrm{m}$ in width. Lateral triangular spaces are present. Their density is 6-9 rays on tangential milimeter. In radial section, the rays appear heterogeneous, because they have thicker walled cells, as ray tracheids, beside the thinner-walled parenchymal body cells, and are all procumbent. The ray cells have 8-20 $\mu \mathrm{m}$ tall, the marginals are slightly taller, of 25-30 $\mu \mathrm{m}$. The horizontal walls of the ray cells are smooth and usually pitted, and the tangential end-walls are relatively thick, of 1.5-2 $\mu \mathrm{m}$ the simple wall and are nodular, as typical juniperoid thickenings. The ray tracheids are located in the ray-body or marginally, and have smooth or slightly rough thick walls. The indentures are missing or difficult to observe. Spiral thickenings are usually absent. The cross-fields are typical cupressoid, with 1-2-4(-6) cupressoid oculipores of $8-10 \mu \mathrm{m}$ in diameter, usually in vertical pairs arranged, and with slit-like inclined apertures, of 2-5 $\mu \mathrm{m}$.

Radial or axial resin canals - are absent.

Mineral inclusions - are not present

\section{Affinities and discussion}

The cupressaceous xylotomy of the 7 specimens studied here, assigned to the genus Protojuniperoxylon Eckhold, are definitely pycnoxylic and homoxylic (or tracheidoxylic - sensu Creber, 1972), having radial pitting on tracheids of mixed type, no resin canals, rare parenchyma but with nodular horizontal walls, rays exclusively uniseriate and cross-fields with 1-2(4-6) cupressoid pits with slit-like inclined apertures, arranged in 1-2 vertical pairs, or irregularly to slightly alternately and with nodular tangential end-walls of ray cells as typical juniperoid nodules (i.e. juniperoid thickenings).

We have discussed above the current status of "Protopinaceae family" and of "Cheirlepidiaceae family" and, lastly, the proposal to be accepted as valid - the family name "Hirmeriellaceae" (Harris, 1979), which is considered correct and valid to be used for the Mesozoic gymnosperms characterized by pollen of Classopollis-type, and was proposed for taxonomic conservation (see Doweld, 2020).

The genus name Protojuniperoxylon was established by Eckhold in his PhD Thesis (Eckhold, 1921, 1922, p.491), to designate Mesozoic cupressaceous wood of Juniperustype, described like this: "Annual rings more or less 

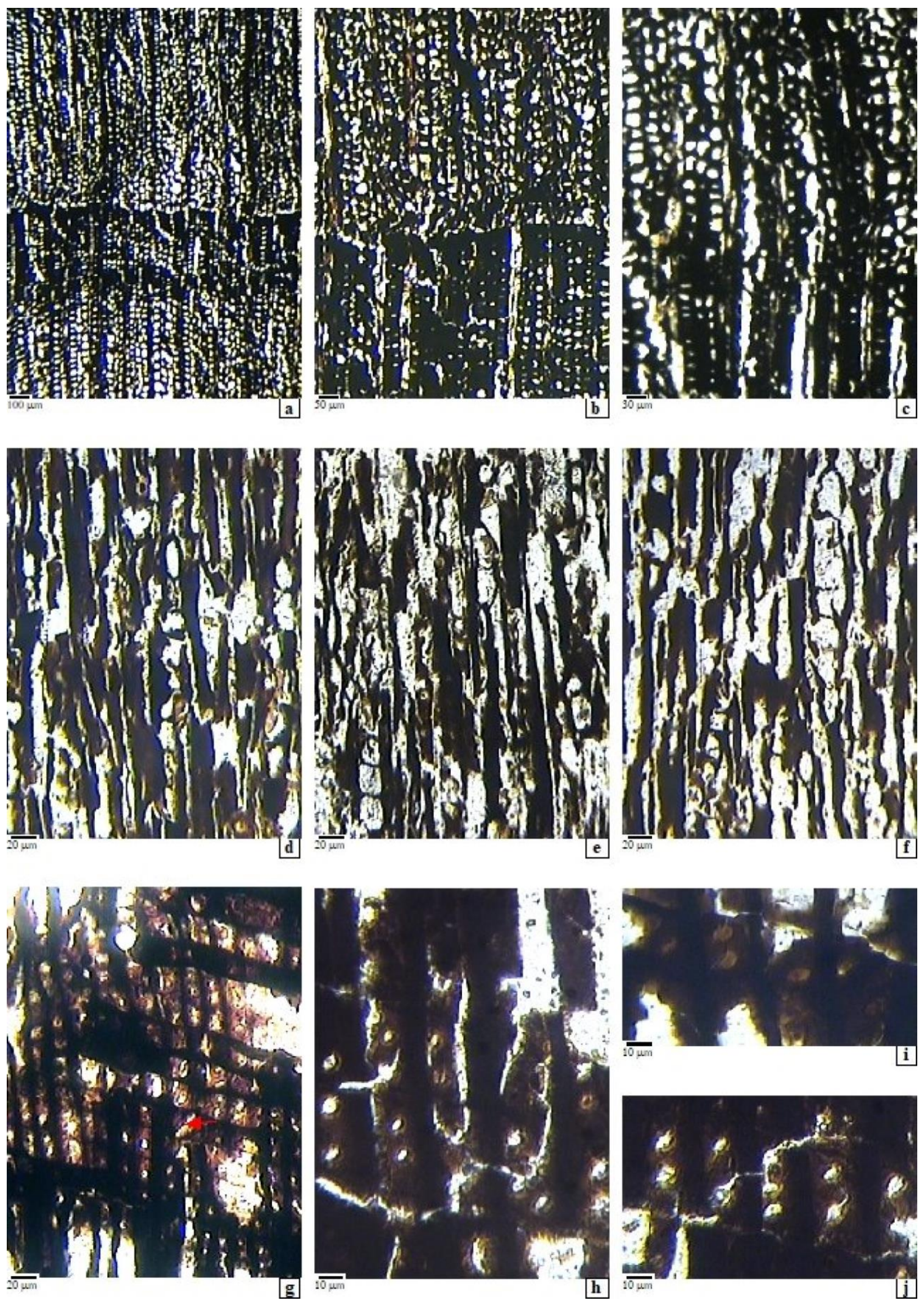

Fig. 2 Protojuniperoxylon holbavicum sp. nov. (inventory no. 27706).

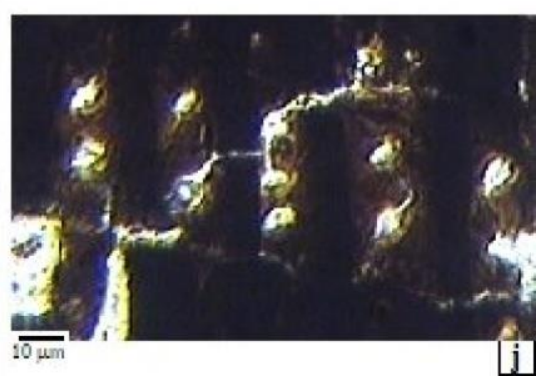

a-c: Cross section - tracheids polygonal with rounded corners, and linear rays; d-f: Tangential section - uniseriate rays with biseriate storeys with polygonal ray-cells, with lateral empty spaces; unpitted tracheids; g-j: Radial section -uniseriate radial pitting on tracheids as hexagonal pits; araucarioid cross-fields with vertical pairs of pits or slightly irregular; end-wall with juniperoid thickenings (see arrow). 
marked, tracheid pits in various transitional arrangements, 'Abietineentüpfelung' absent, but 'Juniperustüpfelung' present, no resin canals, cupressoid pits in crossfield, axial parenchyma occasionally present" (Eckhold, 1921 fide Bodnar, 2017).

In fact, few species were described for this genus, sometimes revised, as follows:

Protojuniperoxylon maidstonense (Stopes) Eckhold, 1921 was taken as type-species, even if, initially, this wood type was described from the Cretaceous of Maidstone (Great Britain), as a species of Cedroxylon, by Stopes (1915). It has uniseriate radial pitting on tracheids, few axial parenchyma with nodular end wall, and cupressoid cross-fields (see Bodnar and Artabe, 2007).

Protojuniperoxylon hornei (Seward and Bancroft) Eckhold, 1921 was initially described as Jurassic species of Cedroxylon and later, of Scotoxylon (Vogellehner, 1968), so, it could be doubtful for comparison.

However, Zhang et al. (2000) described a Scotoxylon yanqingense Zhang and Zengh, a Late Jurassic Chinese species, as representing secondary wood of Protojuniperoxylon-type, but devoid of axial parenchyma.

Protojuniperoxylon ischigualastensis (Bonetti 1966) Bodnar and Artabe, 2007 is a Triassic wood from Argentina, which has mixed radial pitting on tracheids, cupressoid cross fields, juniperoid thickenings on the end walls of ray parenchymal cells and nodules on the horizontal walls axial parenchyma, which are typical for $J u$ niperus wood-type.

Protojuniperoxylon arcticum Selling, 1951 described on some Mesozoic root-wood remains from Hope Island (Svalbard, Norway) is poorly identified, for it is most probably a bennettitalean taxon (Cycadeoidea Buckland), showing interactions with chytrid fungi and bacteria (see Strullu-Derrien et al., 2012; McLoughlin and StrulluDerrien. 2016).

Ruiz and Bodnar (2019) revised a Mid Triassic species of Cupressinoxylon of Bodnar et al. (2015) as Juniperoxylon zamunerae (Bodnar et al.) Ruiz and Bodnar, and made an extensive discussion on the wood structure of Juniperustype including in a table the described species of Protojuniperoxylon together with Mesozoic and Cenozoic species of Juniperoxylon, all of them characterized by the presence of nodular ray parenchyma end-walls (i.e. 'Juniperustüpfelung'), details also observed in our material. Also, very useful is the discussion of Akkemik (2021), who described and identified an Early Miocene species of Juniperoxylon from Turkey, as having typical xylotomy of Juniperus type, proposing even an identification key that includes also some species of Protojuniperoxylon.

Our material displays the typical xylotomical features of Juniperus type as cupressaceous wood with mixed 1-2 seriate radial pitting on tracheids, rare or absent parenchyma, and usually uniseriate rays with cupressoid crossfields in vertical pairs and juniperoid nodules on the tangential walls of the ray cells. Evaluating these details comparatively with those included in Table 1 from Ruiz and Bodnar (2019), and using the identification key of
Akkemik (2021), we observe that our specimens are not identical to any described species. Thus, we describe a new species named here Protojuniperoxylon holbavicum sp. nov. The designated holotype is the sample 27706 (inventory number), kept in "Grădinaru Collection", hosted by National Geological Museum, from Bucharest.

\section{The diagnosis of the species Protojuniperoxylon holbavicum sp. nov.}

Secondary tracheidoxylic wood, with thick-walled tracheids with uniseriate pitting, or even biseriate of mixed type, parenchyma absent or few and with nodular horizontal walls, heterogeneous uniseriate rays with juniperoid nodules on tangential walls or ray cells, crossfields with 1-2(4-6) small cupressoid pits per field, as 1-2 vertical pairs pits and when more, slightly irregular or alternate, and having slit-like inclined apertures.

Genus Brachyoxylon Hollick and Jeffrey, 1909

Brachyoxylon holbavicum Iamandei, Iamandei and Grădinaru, 2018

Fig. 3, a-i.

\section{Material}

The studied material is represented by 7 samples of silicified wood collected from the Holbav locality, on Maiului brook. All the studied samples are fragments of trunk or thick branches, with decimetric size and dark to black colored. By hand lens or even by naked eye, the regular fibrous structure without vessels suggests a conifer wood. The specimens, with the following field numbers: 1089, 1090, 1093, 1094, 1096, 1102, 1105, belong to "Grădinaru Collection", and are stored at the National Museum of Geology, in Bucharest, under the inventory numbers: 27711, 27712, 27713, 27714, 27715, 27716, 27718.

\section{Microscopic description}

Growth rings - well developed, with tracheidoxylic structure, abrupt or gradual transition, distinct boundaries, no resin canals.

Tracheids - with polygonal cross section, usually quadrangular with rather thick and slightly corrugated walls in the early-wood, diameters of 20-40(60) $\mu \mathrm{m}$ and wall thickness of 5-7(8) $\mu \mathrm{m}$ (double wall), quite similar in the late-wood. Between two successive rays, 1-12 radial regular rows tracheids appear and intercellular spaces are present. Density is $836-1520$ tracheids per square $\mathrm{mm}$. On tangential walls the pitting is usually absent. The radial pits are of mixed type, either uniseriate, with round pits, spaced or contiguous and variably flattened (flattening index: $\mathrm{d} / \mathrm{D}=0.79-0.88$ ), or biseriate, with round to oval pits, of $19-24 \mu \mathrm{m}$ the diameter, with round to oblique-elliptic apertures of 7-10/3-5 $\mu \mathrm{m}$, in opposite or alternate arrangement, sometimes contiguous, combined with short uniseriate portions. There are no crassulae or helical thickenings, but sometimes striations are present. Axial parenchyma - is absent. 

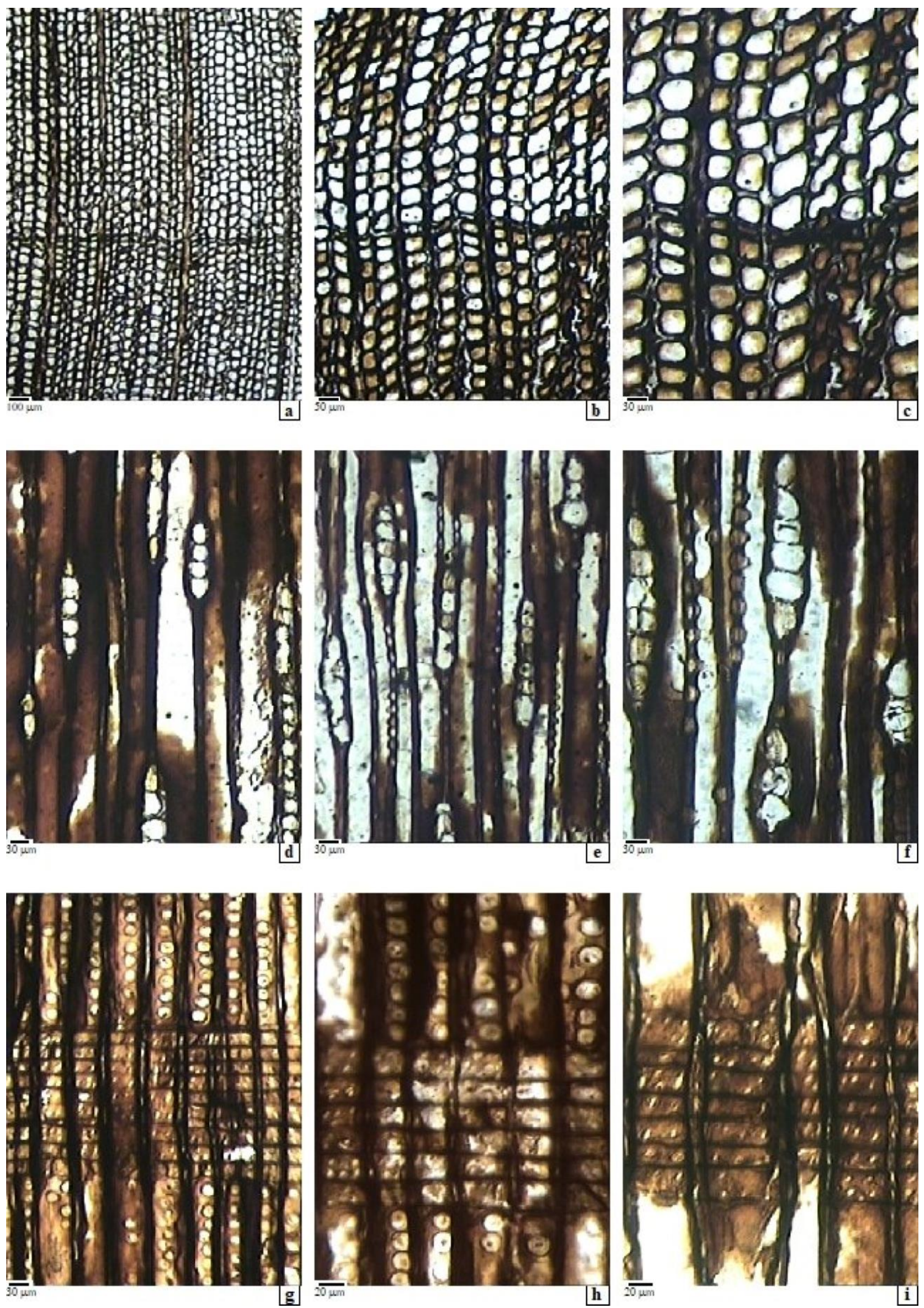

Fig. 3 Brachyoxylon holbavicum Iamandei, Iamandei and Grădinaru, 2018. (inventory no. 27711).

a-c: Cross section - tracheids polygonal with rounded corners, and linear rays; d-f: Tangential section - pitting on tracheids - absent; rays uniseriate; g-i: Radial section - radial pitting of mixed type on tracheids, pits hexagonal and, when biseriate, alternate; cross-fields with 2-3(4) cupressoid to araucarioid in 1 row or, when more numerous, in 2-3 superposed rows. 
Rays - in cross-section appear thin, with linear trajectory, from rectangular cells radially elongated, with smooth unpitted horizontal walls. Tangentially they appear exclusively uniseriate, with $2-17(-25)$ cells in height, sometimes more. And, sometimes, the taller rays have 1-2 short biseriate storeys of the same thickness as a single cell. Lateral empty spaces commonly appear. Ray-density is of 7-12 rays per tangential horizontal millimeter. The rays are homogeneous, with parenchymal cells all procumbent, of $20-24 \mu \mathrm{m}$ in height, in the marginal rows taller, of 28-35(-50) $\mu \mathrm{m}$. The horizontal walls are moderately thick walled, 4-6 $\mu \mathrm{m}$ for the double wall (sometimes thicker), and the outer wall of the marginals is slightly corrugated. Tangential wall is relatively thick. Indentures are not visible. The cross-fields have 1-6 cupressoid pits, tending to podocarpoid, usually hexagonal-rounded to oval, with diameters of 9-15(18) / 6-8(10) $\mu \mathrm{m}$ and with tilted elliptic apertures of 5-8 / 3-5 $\mu \mathrm{m}$. In normal fields the pits arrangement is 1-3(-4) pits in horizontal row and, in the taller rays, 4-6(-9) pits in 1-2(3) horizontal rows, alternately or slightly irregularly arranged.

Radial or axial resin canals - are absent.

Mineral inclusions - are not present.

\section{Affinities and discussion}

All the 7 samples of fossil wood studied here present the next xylotomy: typical tracheidoxylic structure with thick-walled tracheids, having radial pitting of mixed type, with rays mostly uniseriate showing cupressoid cross-fields (tending to araucarioid). All these xylotomical details are consistent with those of the genus Brachyoxylon Hollick and Jeffrey.

This genus was created by Hollick and Jeffrey (1909), having as type species Brachyoxylon notabile Hollick et Jeffrey, with a very elliptic diagnosis: "tracheidoxyl devoid of normal secretory ducts, with radial pitting of mixed type, araucarioid cross-fields and other ray walls, integer" (see Philippe, 1993; Philipe and Bamford, 2008). The occasionally presence of traumatic canals is considered as a result of injury, or of freezing (see Phillipe, 1995).

In order to identify the specimens studied here at species level, we evaluated other fossil forms previously described. We noted that some species are no longer considered to be Brachyoxylon species, or are doubtful, so they should be excluded from discussion (see Iamandei et al., 2018).

There are many forms of Brachyoxylon described showing a large spread of this Mesozoic genus on the planet and we have quoted and discussed, in detail, some of them (in Iamandei et al., 2018). They were described from Japan (Iijima et al., 1989), from Mexico (CevallosFerriz, 1992), from USA (Hickey et al., 2011), from Argentina (Vera and Césari, 2012; Bodnar et al., 2013), all of them having various specific xylotomical details, partially similar to our material.

But the European species Brachyoxylon saurinii described by Boureau and Serra (1961), B. avramii and B. dobrogiacum described by Iamandei and Iamandei (2005), B. serrae described by Phillipe et al. (2011) and, especially $B$. holbavicum, described by us from the same area (Iamandei et al., 2018) are closer to our studied specimens. And, related to this, the debate on Mesozoic palaeoenvironment of large European forests made by Garcia et al. (1998) is very interesting and, also, the complex biogeographic analysis of Gondwanian Mesozoic forests of Philippe et al. (2004).

In summary, taking into account the comparative table (see Table 1, in Iamandei et al., 2018) and the synthetic description of the specimens studied here (mixed radial pitting on tracheids, axial parenchyma absent, uniseriate rays medium-tall, cross-fields with cupressoid pits, tending to podocarpoid, in quassi-araucarioid arrangement), we consider our samples to perfectly fit to the diagnosis of Brachyoxylon holbavicum Iamandei, Iamandei and Grădinaru, a species previously identified in the same area (see Iamandei et al. 2018).

Brachyoxylon cristianicum Iamandei, Iamandei and Grădinaru, 2018

Fig. 4, a-i.

\section{Material}

The studied material is represented by 13 samples of silicified wood collected from the Holbav locality, on Maiului brook. All the studied samples are fragments of trunk or thick-branch fragments, with centimetric to decimetric size, dark color and, by hand lens or even naked eye, the regular fibrous structure without vessels is visible, evidence of a conifer wood. The specimens, with the following field numbers: 1071, 1072, 1073, 1075, 1076, 1080, 1081, 1101, 1103, 1108, 1110, 1112, 1113b belong to "Grădinaru Collection" and are stored at the National Museum of Geology, in Bucharest, under the inventory numbers 27678, 276789, 27680, 27681, 27682, 27684, 27685, 27686, 27717, 27687, 27688, 27689, 27690.

\section{Microscopic description}

Growth rings - in cross-section show a tracheidoxylic structure without resin canals, usually with abrupt transition from early- to late-wood, and with rather distinct growth-ring boundary. Resin canals absent.

Tracheids - with polygonal (quadrangular) cross-section with rounded corners, unequal in size, diameters of 2035-(45-65) $\mu \mathrm{m}$ and with thick walls, of 5-8(9) $\mu \mathrm{m}$ the double wall, usually curled by compression. The latewood is represented by 2-3 rows of thick-walled and radially flattened cells (radial diameter of 5-10 $\mu \mathrm{m}$ ). Intercellular spaces are present. The interradial bundles have 1-10 radial regular rows of tracheids. Density is of 9921518 tracheids per $\mathrm{mm}^{2}$. Tangential pitting is absent. Radial pitting is usually uniseriate or biseriate of mixed type. When biseriate, the pits appear alternate or opposite and contiguous on short rows often continued by uniseriate portions and do not occupy all the length of the wall. The pits have round to hexagonal borders, diameters 

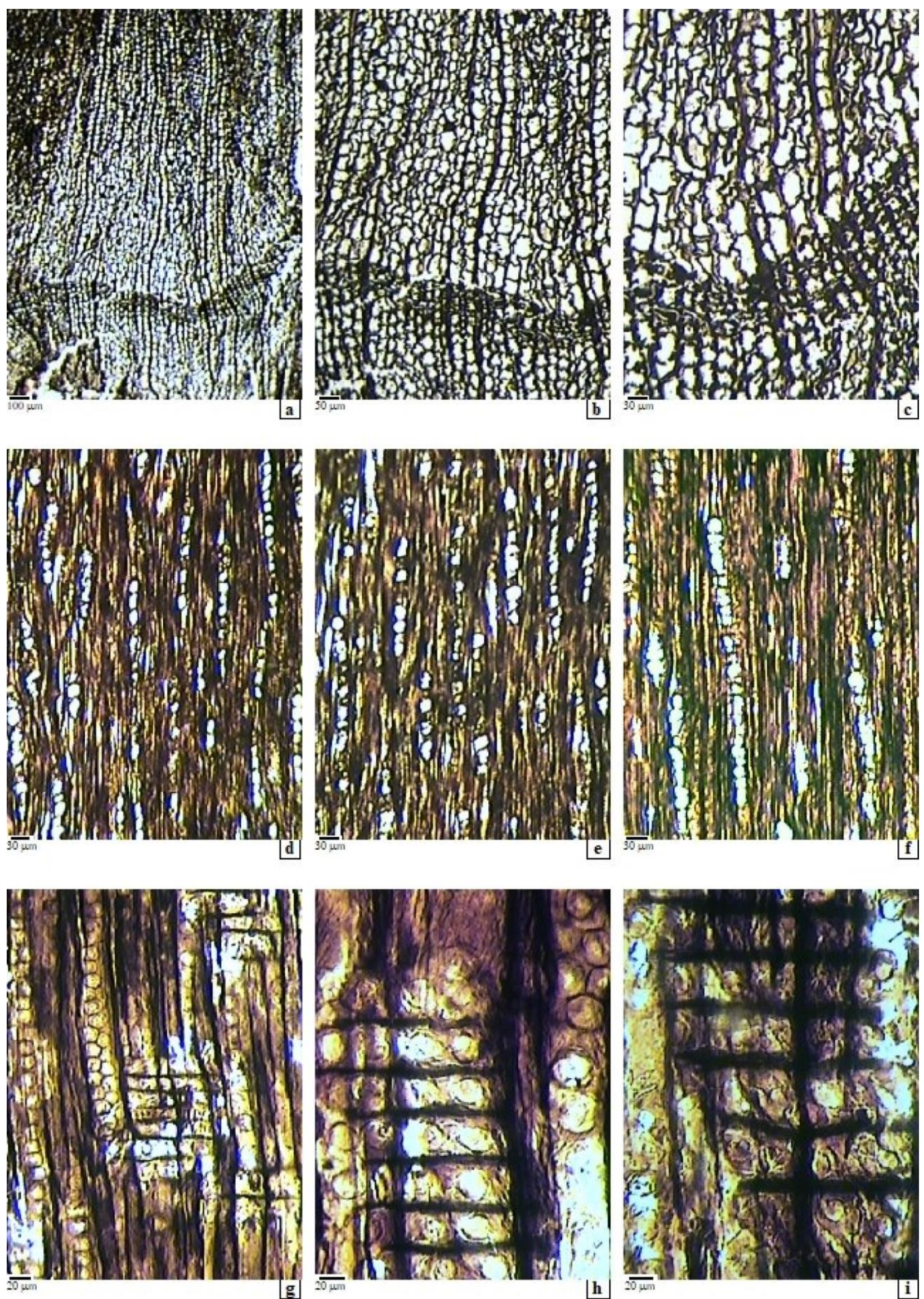

Fig. 4 Brachyoxylon cristianicum Iamandei, Iamandei and Grădinaru, 2018 - inventory no. 27690(field no. 1113b).

a-c: Cross section - thick-walled tracheids, polygonal, with rounded corners and curled walls; dispersed parenchyma cells; linear rays; d-f: Tangential section - uniseriate rays with polygonal ray-cells and biseriate storeys; unpitted tracheids; parenchyma with end-walls smooth or nodular and resin content inside; g-i: Radial section - radial pitting on tracheids of mixed type; cross-fields with 2-3 cupressoid or araucarioid in a single row or, when more numerous, in 2-3 superposed rows. 
of 18-22 $\mu \mathrm{m}$, and are variably flattened when contiguous $(\mathrm{d} / \mathrm{D}=0.65-0.88)$, bearing round or tilted elliptic apertures of 7.5-10 / 2-3 $\mu \mathrm{m}$. Sometimes crassulae or helical thickenings can appear.

Axial parenchyma - in cross-section appear few, dispersed, often difficult to identify among the tracheids. Vertically, sometimes they can show simple pits. The horizontal walls are thin and smooth, or slightly nodular. Sometimes, a resin content is present inside the cells, as plugs or granules.

Rays - in cross-section appear usually uniseriate and linear. In tangential section, the rays show 1-20(-25) cells in height (i.e. 30-570(-650) $\mu \mathrm{m})$. The taller uniseriate rays have biseriations, which give sometimes a fusiform aspect. The ray-cells have polygonal rounded to oval section, marginal spaces and sometimes have dark content. The ray density is of 5-11 rays per horizontal millimeter. The rays appear homogeneous, with cells all procumbent, of 20-30 $\mu \mathrm{m}$ tall, relatively thick walled, of 4-5(7) $\mu \mathrm{m}$ the double wall. Within the marginal rows, but not only, the ray cells are taller, of $30-40 \mu \mathrm{m}$, and have slightly corrugated outer walls. The cross-fields are of araucarioid type, have 1-6(-8) pits, hexagonal or slightly rounded to oval, of cupressoid type, tending to podocarpoid or araucarioid. They have 15-19/8-12 $\mu \mathrm{m}$ in diameters, and show circular or short elliptic tilted apertures of 10-14/5-7 $\mu \mathrm{m}$. The pits are arranged in 1-2(3) rows per cross field, within ray body fields, or in the marginal fields and are alternate to slightly irregular.

Resin canals - are absent.

Mineral inclusions - are absent.

\section{Affinities and discussion}

From the microscopic study of all the standard oriented thin sections, we selected 13 specimens having similar generic characters, represented by tracheidoxylic structure, radial pitting of mixed type on tracheids and araucarioid cross-fields, which are consistent with the structure of Brachyoxylon wood-type (see Philippe, 1993; Philipe and Bamford, 2008), but a slightly different from the above-described species.

We do not repeat the discussion from above on the genus creation and about the previously described species, but, consulting the comparative Table 1, from Iamandei et al. (2018), we observed beside the generic characters some other specific details that are different of those of the above-described species.

Thus, we observed that the radial tracheidal pitting of mixed type are commonly discontinuous, the axial parenchyma is present, as dispersed cells with slightly nodular horizontal walls and with resin content inside.

Other features are: the relatively tall uniseriate rays with biseriations, up to fusiform aspect, homogeneous and with cross-fields with 1-6(-8) hexagonal to rounded cupressoid oculipores, alternately arranged (araucarioid) to slightly irregular. All these details almost identical to those of the species Brachyoxylon cristianicum, which was previously described from the same area (Iamandei et al., 2018).

From these characteristics, we attribute all the 13 here studied specimens coming from Holbav and Cristian to the above specified form: Brachyoxylon cristianicum Iamandei, Iamandei and Grădinaru, 2018.

Division Ginkgophyta Bessey, 1907

Class Ginkgopsida Engl., 1897 (in Engler and Prantl, 1897)

Subclass Ginkgoidae Engl., 1897

Order Ginkgoales Gorozhankin, 1904

Family Ginkgoaceae Engl., 1897

Genus Palaeoginkgoxylon Feng, Wang and Rößler, 2010 Palaeoginkgoxylon sp.

Fig. 5, a-i.

\section{Material}

The studied material is represented by two samples of silicified wood, of decimetric dimensions, found in the Holbav locality area, on the Maiului brook. The studied samples are trunk or thick-branch fragments, dark to black color and by hand lens or even by naked eye a regular fibrous structure is visible. These two samples have the field-numbers 1032, 1036 in "Grădinaru Collection" and are stored under the inventory numbers 27674 and 27675, at the National Museum of Geology, in Bucharest.

\section{Microscopic description}

Growth rings - in cross sections show a tracheidoxylic structure with rather indistinct boundaries, with few parenchyma and sometimes with axial canals, most likely mucilaginous. And, the structure is marked by the presence of some swollen mucilaginous cells among the tracheids and also, inside the rays.

Tracheids - with polygonal cross-section, unequal in size and with rounded corners, with quite abrupt transition from the early- to the late-wood; thus, they have 25-35 / $35-40 \mu \mathrm{m} \mathrm{r} / \mathrm{tg}$ diameters in the early-wood, smaller in the late-wood, and with relatively thick walls, of 4-7 $\mu \mathrm{m}$ the double wall. Between two successive rays there are 2-12 radial regular rows of tracheids, and the density is 13601728 tracheids per $\mathrm{mm}^{2}$. The tangential walls of the tracheids are usually unpitted. On the radial walls the pitting is of mixed type, with pits polygonal to slightly rounded, spaced or contiguous, in a single vertical row or, rarely, biseriate, alternate or slightly irregular to opposite. The bordered pits are slightly flattened, relatively small, of 8$10(15) \mu \mathrm{m}$ in diameter. Often, only the pit chamber is visible, the aperture is small round to short elliptic, of 1.5-2(3.5) $\mu \mathrm{m}$. Crassulae or helical thickenings were not observed. In radial view sometimes the endings of the tracheids appear slightly bended, overlapping each other and bear some dark content inside.

Axial parenchyma - is visible in cross-section, sometimes as swollen cells dispersed among the axial tracheids, most probably with mucilages, commonly close to rays, or 


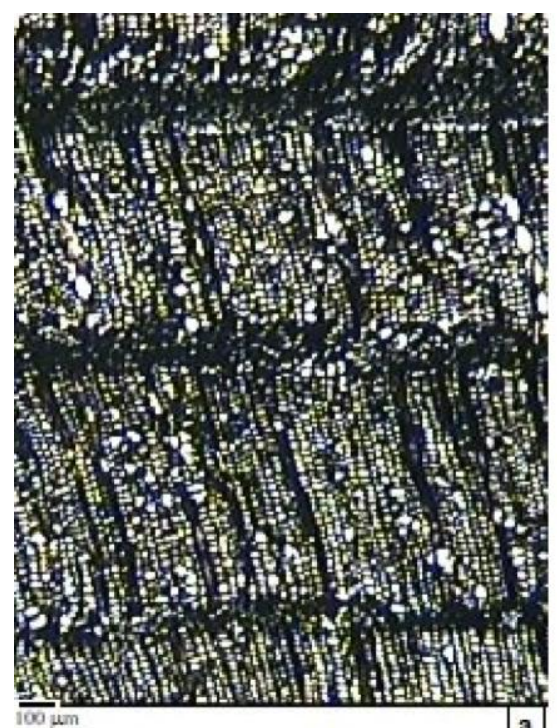

a
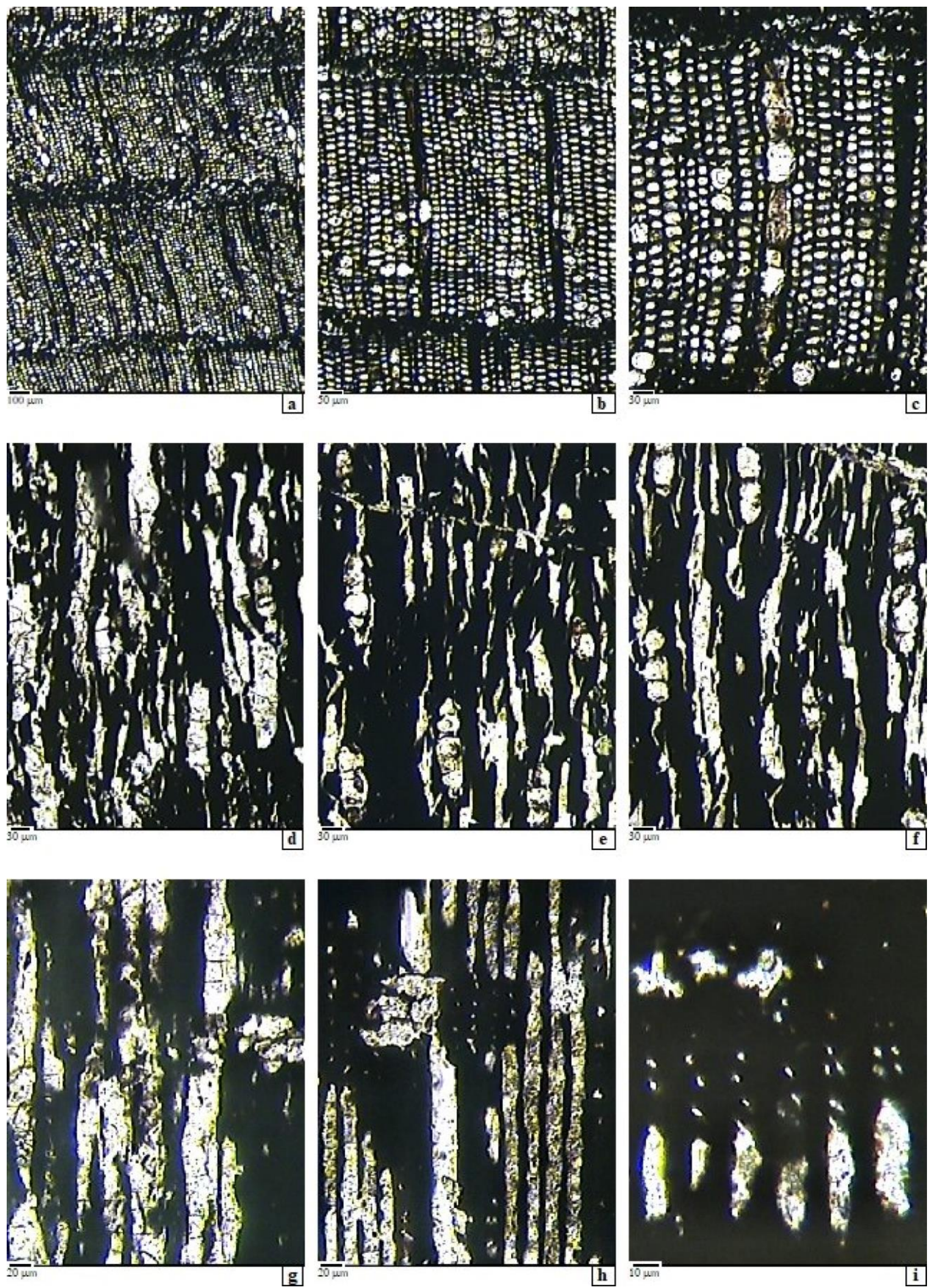

Fig. 5 Palaeoginkgoxylon sp. - inventory no. 27674 (field no. 1032).

a-c: Cross section - tracheids polygonal with rounded corners; disperse mucilaginous cells; linear rays with mucilaginous ray-cells; d-f: Tangential section - unpitted tracheids; uniseriate rays with inflated secretory ray-cells; g-i: Radial section - radial pitting on tracheids usually uniseriate, of mixed type, with hexagonal pits or rounded; cupressoid cross-fields with 2-3 superposed rows of 13 pits. 
isolated, or in short vertical rows, sometimes difficult to observe due to poor preservation.

Rays - are thin, linear in tranversal view, with inflated secretory cells inside, and have simple pits. Tangentially, the rays are uniseriate and have 1-7(-16) cells, (i.e. 20$180(-350) \mu \mathrm{m}$ high). Sometimes, the taller rays have some few biseriate storeys. The ray-cells have polygonal to rounded shape or seem inflated and full of white substance, most probably mucilaginous. In some cases, on the tangential walls, simple pits are present. Ray density is 7-12 rays per horizontal tangential millimeter. In radial section the rays appear heterogeneous, because, beside the normal parenchymal cells, secretory cells occur, the cells are all procumbent; $19-20(-28) \mu \mathrm{m}$ high and with moderately thick-walled: 3-6.5 $\mu \mathrm{m}$ the double wall. The cells of marginal rows are slightly taller, of 28-30(-40) $\mu \mathrm{m}$. The cross-fields are of cupressoid type, having 1-4(6) pits or more, as rounded to oval cupressoid pits of 4$8(-13) \mu \mathrm{m}$ in diameter, with circular or short elliptic inclined apertures of 1-3.5 $\mu \mathrm{m}$. Their arrangement is alternate or slightly irregular, on 1-2(-3) rows. In some cases, the walls of ray cells seem to be slightly wrinkled, but few details can be observed, due to poor preservation.

Axial canals - rarely were found, and only partially, probably at the limit of the vascular cylinder with the pith (Fig.5, photo a, arrow).

\section{Affinities and discussion}

Some xylotomical features, such as presence of inflated axial parenchyma cells, idioblasts, tracheids with curved tips and with opposite pit pairs separated by crassulae, cupressoid cross-fields, with irregular aspect, which are evidence of a wood structure similar to the current Ginkgo, a living fossil naturally surviving in China.

There are several fossil stem genera described by the study of remains of fossil ginkgophyte trunks found in different Mesozoic sites in the world: Ginkgoxylon (Saporta) Süss 2003; Proginkgoxylon (Khudajberdyev) Zheng and Zhang (in Zheng et al., 2008); Szeioxylon Wang, Jiang et Qin, 1994; Sinopalaeospiroxylon Zhang et Zheng, 2006 (in Zhang et al., 2006); Primoginkgoxylon Süss, Rößler, Boppré and Fischer, 2009; Palaeoginkgoxylon Feng, Wang and Rößler, 2010; and Baieroxylon Greguss, 1961 (see in Martínez and Lutz, 2007).

Taking into account the observed xylotomical details of our specimens which are very similar to Palaeoginkgoxylon of Feng, Wang and Rößler (2010), we compared the description of our specimens with the diagnosis and description of Palaeoginkgoxylon, which has primary structure and pith (absent in our material), and also a welldeveloped pycnoxylic secondary xylem, with tracheids slightly irregularly arranged. In radial section, the tracheids show bent ends overlapping each other, close to the intersection with rays, and have radial pitting usually uniseriate; the ray cells are irregularly pitted on the horizontal walls and the cross-field pits are cupressoid; also, some axial parenchyma is present.
We have studied two fragmentary specimens that represent only the secondary wood, and showing similar features, even though they are rather badly preserved. Thus, we observed the radial pitting usually 1-2 seriate of mixed type on tracheids, the cross fields with numerous cupressoid pits, irregularly or alternately arranged and the presence of swollen parenchyma cells. The central part of the stem is absent. In the first part of our study (see Iamandei et al., 2018) we described some other wood remains found in Hobav area, having similar anatomical features, and were attributed to Palaeoginkgoxylon sp.

The studied two new specimens were collected from the same area and show a very similar xylotomy; for this reason, we assign them to the same form, Palaeoginkgoxylon sp., hoping for a better-preserved material in order to be described at species level.

In this context, we mention that Givulescu and Czier (1990) gave firstly a short macroscopic description and figuration of a well preserved Ginkgoites leaf from the Șuncuiuș area (Apuseni Mountains). However, it is worth to mention, that some years after, Czier (1994, 1998, 2000, 2005) has restudied the material, has revised the entire Ginkgo foliage literature of the Carpathian Basin, described and figured both macro- and microscopically numerous new specimens, new species and combinations, and has elaborated for the ginkgoalean leaves a new determination method based on mathematics. Finally, Czier (1998) proposed the transfer of Ginkgoites and Baiera to the genus Ginkgo. Czier's proposal seems to be correct, and we support it as acceptable, because in addition to the similar foliage structure of these genera, our Jurassic material is very similar in its xylotomic features to the current Ginkgo wood.

Division: Cycadeoidophyta Taylor 1981

Class Cycadeoidopsida Scott, 1923

Order: Bennettitales (Engler, 1892) Meyen, 1984

(=Cycadeoidales Berry, 1916)

Family Williamsoniaceae (Carruthers, 1870) Nathorst, 1913

Genus Bucklandia Brongniart, 1828

Bucklandia sp. A.

Fig. 6, a-i; Fig. 7, a-i.

\section{Material}

The studied material is represented by a piece of silicified wood collected from Holbav area, on Maiului brook. This specimen has the field-number 1107, in "Grădinaru Collection", and is stored now at the National Museum of Geology in Bucharest, under the inventory number 27719.

\section{Microscopic description}

In cross-section, the structure of the wood is of gymnospermous type, and some details (such as the presence of the typical idioblasts and axial mucilaginous canals) suggest a cycadeoid polyxylic stem structure, which is also supported by the presence of scalariform thickenings of 

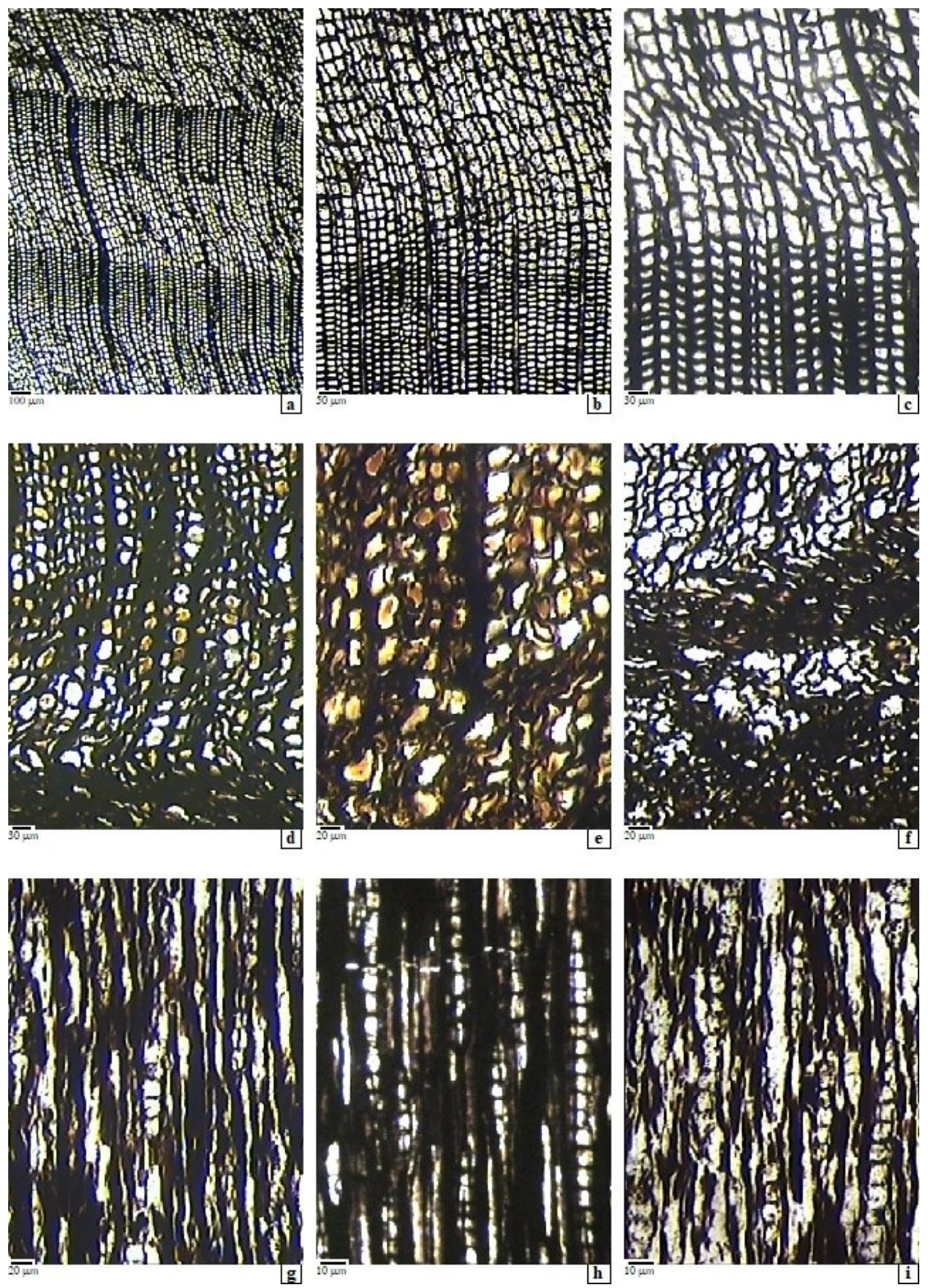

Fig. 6 Buckladia sp. A. - inventory no. 27719 (field no. 1107).

a-f: Cross section - gymnosperm structure with tracheids rectangular with rounded corners, thin curled walls in the early-wood, thick walled in the late-wood; idioblasts between tracheids; d-e: Numerous secondary rays; g-i: Tangential section - unpitted tracheids; uniseriate rays. 

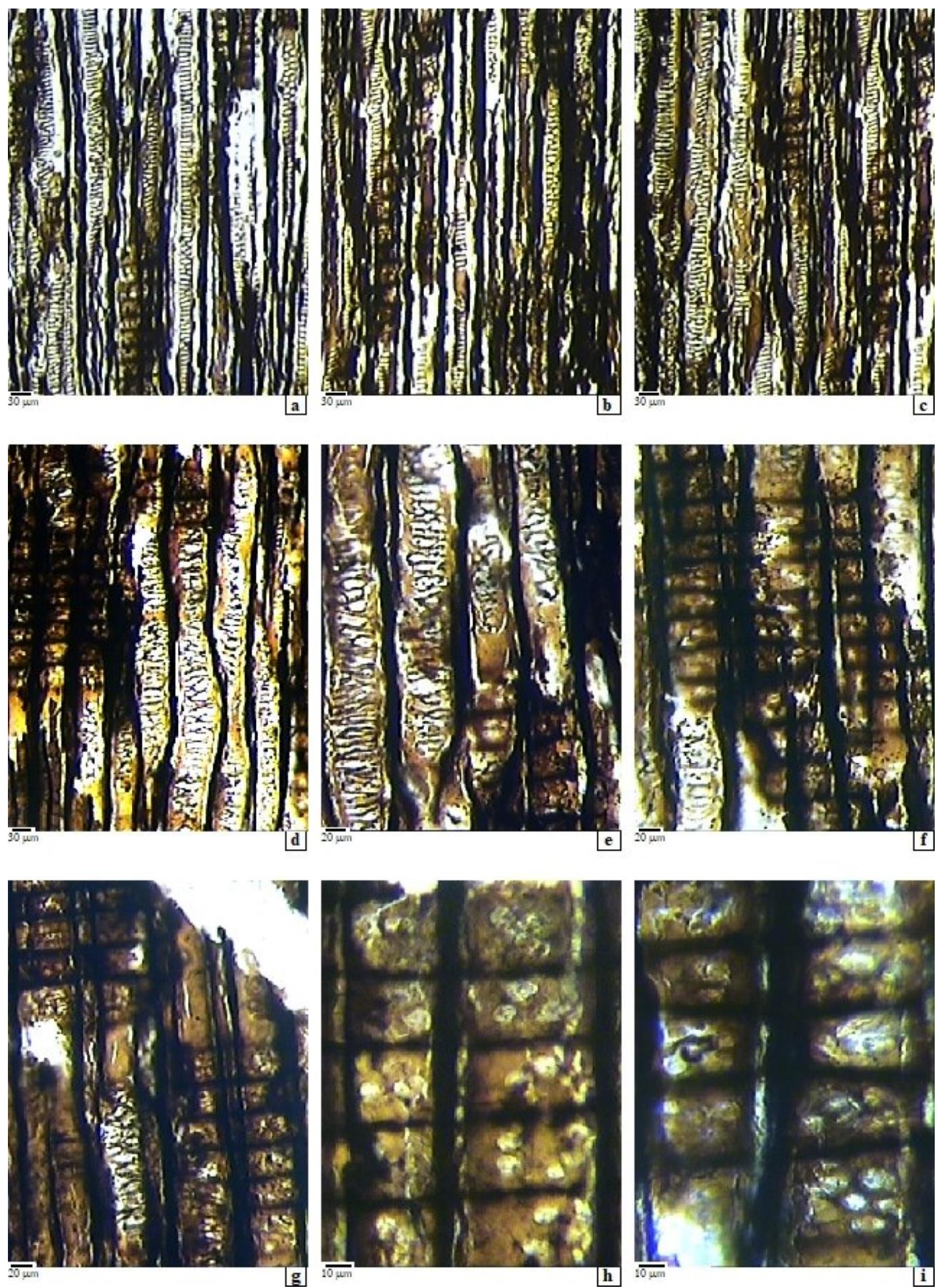

Fig. 7 Buckladia sp. A - inventory no. 27719 (field no. 1107).

a-i: Radial section - d-g: - scalariform thickenings of Zamia type on tracheids, with reticular aspect; g-i: - araucarioid cross-fields with alternate in 2-3 superposed rows. 
Zamia type on the tracheids in vertical view (Greguss, 1968), so, the xylotomic description will be adequate:

Pith - unfortunately, is absent in our fragmentary samples which does not retain the axial part of the stem, so we did not have the possibility to describe its component elements (as parenchyma cells, idioblasts, medullary vascular bundles and mucilaginous canals).

Cylindrical vascular system - in cross section, is represented by some alternative growth rings of secondary xylem and phloem (not as annual rings) and numerous thin secondary rays, so giving a polyxylic structure (Fig. $6 a)$, crossed by wide multiseriate primary medullary rays which connect the axial pith with the cortex (but this aspect does not appear in our sections). The cambial cells are recognized with difficulty, since they are very similar to the neighboring cells. The xylem has rectangular or square tracheids, in gradual transition from early- to the late-wood, with $\mathrm{r} / \mathrm{tg}$ diameter of 25-65 / 10-15-30 $\mu \mathrm{m}$, with relatively thick walls, of 4-8 $\mu \mathrm{m}$ the double wall, (Fig. 6a-f). Their walls are often corrugated, by compression. On the radial walls, the tracheids show uni- to biseriate bordered pits, rounded to hexagonal, contiguous and flattened, sometimes alternate, when biseriate (Fig. 7g, arrow). The pits have diameters of 9-12/8-15 $\mu \mathrm{m}$, with round to elliptical apertures. Very obvious are the scalariform thickenings of Zamia type, which are often connected by inclined bars, giving a reticular appearance (Fig. 7a-e). No perforations were observed. The tangential walls are not pitted (Fig. 6g-i). The phloem has parenchymal cells, (unclear if they are sieve cells), thickwalled fibres, secretory idioblasts, and sclerenchymal cells (Fig. 6d-e).

Rays - in transversal and tangential sections, the primary rays were not observed in our fragmentary material, but numerous secondary rays appear, giving a manoxylic aspect to the structure. They are uniseriate, sometimes 2($3)$-seriate, of low to mid tall, and are composed of parenchyma cells and few secretory idioblasts, so they are heterogeneous. The ray cells are rounded to rectangular in outline, the idioblasts are similar or are slightly elongate and, in radial view, appear all procumbent. In cross-fields they have 2-6(9) oculipores usually in two superposed rows arranged (Fig. 7d-i).

Cortex - is not present in our sample, so parenchymal cells, idioblasts, mucilage canals and leaf traces, were not observed.

\section{Afinities and discussion}

Evaluating the general image of the wood structure in cross section, we noticed some details that indicated a possible cycadeoid stem-structure of polyxylic type, by the presence of idioblasts and mucilaginous canals. Thus, we searched for more xylotomical details in order to identify the unknown structure.

As is known, the Cycadeoidophyta is a Mesozoic extinct taxon, which include two families: Cycadeoidaceae Buck. (or Bennettitaceae Engl.) - with the genera Cycadeoidea
Buck. (or Bennettites Caruthers) and Monanthesia Wieland; they have a barrel-shaped trunk, like a large pineapple, with a crown of leaves; the second family, Williamsoniaceae (Carruthers) Nathorst - with Williamsonia Caruthers as type genus, a form with a columnar trunk with frond like leaves at branch tips (see Stockey and Rothwell, 2003). This family includes a lot of described genera of plant-parts, variably named, which send sometimes to a current Cycadalean genus, as follows: Williamsoniella, Nilssoniopteris, Bennettitanthus, Cycadocephalus, Fredlindia, Ischnophyton, Lyssoxylon, Serenopsis, Weltrichia, Zamites, Anomozamites, Otozamites, Podozamites, Ceratozamites, Banatozamites, Pterophyllum, Wielandella, Crossozamia, Dioonites, Eostangeria, Palaeocycas, Pseudoctenis, Ticoa, and many others (see Taylor et al., 2009; Martínez et al., 2012, 2017). Numerous fossil remains of Bennettitales were described from Romania. Thus, in the Holbav-Cristian-VulcanCodlea area Givulescu (1991) cited an Early Jurassic flora (or "Liasic flora") with the presence of Zamites, Nilssoniopteris and Pterophyllum (from Bennettitales) and Phoenicopsis (Ginkgoaceae). In recent decades, Dragastan and Popa (1997), Popa (1997a, 1998, 2000a,b), and Popa and van Konijnenburg-van Cittert (1999, 2006) contributed more to the Early Jurassic flora in the Holbav area, describing Nilssonia cf. undulata, Paracycas sp., Ctenis grandifolia (Cycadales) and Ptilophyllum rigidum, Pterophyllum magoti, P. neagui (as Bennettitales) and beside them - Taeniopteris sp. (Ginkgoales), Phoenicopsis potoniei (Czekanowkiales) and Geinitzia sp. (Conifers). Also, from the Cristian area were described Pachypteris grădinarui, Otozamites mandelslohi, O. molinianus and a Desmiophyllum sp. which belongs, probably, to Czekanowskiales. Also, Dragastan and Popa (1997) and Czier (2016b) advanced some phytostratigraphic schemes based on the Early Jurassic foliar material identified in the Holbav area.

However, there are few genera described in the world from the study of fossil stem remains, often with local importance and with names related to the original fossiliferous site or people (see list in Martínez et al., 2012, 2017; Zhang et al., 2012). For example, Martinez et al. (2017), have described a well-preserved Jurassic bennettitalean specimen from Patagonia, as Zamuneria amyla Martínez, Iglesias and Artabe, and made a carefully documented comparison with the xylotomy of the extant cycadalean genera and also, with all Mesozoic Bennettitalean genera.

The studied specimens show a cycadeoid polyxylic structure with scalariform thickenings on tracheids which indicate similarities with stem of Bucklandia type (see Bosse, 1953; Sharma, 1967, 1969, 1973, 1991; Saiki and Yoshida, 1999) or even with Sahnioxylon (see in Philippe et al. 1999) - the latter being considered "nomen ilegitimum" (see IFPNI -

www.fossilplants.info/genus.htm?id=D46FC51A-7AEB421E-AF52-1A3F90515E43). 
Because the structure of our specimen indicates a columnar polyxylic stem, the sample does not preserve the pith from the central part of the stem and also the cortical zone, both of parenchymal tissue, which were likely easily destroyed during the early stages of fossilization. We cannot see typical parenchymal cells, idioblasts, medullary vascular bundles, mucilaginous canals, and transfusion cells or leaf bases, in the cortex.

However, the polyxylic cycadeoid structure with idioblasts and scalariform thickenings on tracheids, that resemble those in the current Zamia, Ceratozamia (see Greguss, 1968) and are partially similar to the structure of the Jurassic genera Bucklandia Brongniart, Zamuneria Martínez, Iglesias and Artabe and Lioxylon Sharma (see Martínez et al., 2017), which are also characterized by polyxylic stem with centripetal and centrifugal vascular systems and by the presence of numerous idioblasts in the structure.

In the studied Mesozoic areas of Romanian Carpathians, many fossil macro-remains have been described and attributed especially to taxa from Zamites group: Anomozamites, Otozamites, Podozamites, Ceratozamites, Banatozamites (see Givulescu, 1991; Dragastan and Popa, 1997; Popa, 1997, 1998, 2000b; Popa and van Konijnenburg-van Cittert, 1999, 2006; Czier, 1999, 2001, 2008, 2009, 2016a,c, 2018), and such taxa have also been commonly described in Europe (see Barbacka et al., 2014). Thus, from the Lower Jurassic of Anina, Banat region, Romania, Czier (2009) described two Bennettitalean species: Banatozamites calvus Czier, by the study of leaf impresions and Bucklandia aninaensis Czier, by the study of a small stem with petioles, interpreted to belong to the same plant; they have fine longitudinal ridges, and rows of rectangular to rounded-elongated cells.

The specimen studied here has details that resemble a Zamia-type structure (see above), especially due to presence of scalariform thickenings on tracheids, even with reticular appearance (see Greguss, 1968). Also due to the presence of idioblasts and mucillaginous canals, we assign it to Bucklandia $s p$. A, probably representing wood of an extinct form from the Zamites group, commonly present in the Romanian Carpathians (see above).

Regarding the genus Bucklandia, erected by Brongniart (1828), we consider it as a still valid genus, because it was proposed by Doweld (2012) to be conserved. However, Herbst and Crisafulli (2016) ignoring this proposal, described a new genus, Buckya Herbst and Crisafulli, to replace the old genus Bucklandia Brongniart, recommending transfer of all the species previously described to the new proposed genus, as nov. comb. (see Herbst and Crisafulli, 2016, p. 97-98).

But, we observed that there is another possible problem of this name, Buckya, which could become illegitimate, since there are two quasi-homonyms: Buckia Cobos, 1956, which is the name of a current insect from the Order Coleoptera L., and Buckia Rios, Gallego and Guerra, (see in GBIF-online), but is also used to describe a moss, a homotypic synonym for Hypnum Hedw. (Order Hypnales Buck. and Vitt.).

\section{Bucklandia sp. $B$}

Fig. 8, a-i.

\section{Material}

The studied material is represented by three small (centimetric) samples of silicified wood, collected from around Holbav locality area, on Maiului brook. These samples have the field-numbers: 1037, 1038 and 1079, in "Grădinaru Collection" and are stored now at the National Museum of Geology, in Bucharest, under the inventory numbers 27676, 27677 and 27683.

\section{Microscopic description}

Cross-sections of the studied specimens show a wood structure of gymnospermous type (Fig. 8a), with some details indicative of a cycadeoid stem structure, due to the presence of idioblasts and mucilaginous canals (Fig. 8c, $\mathrm{h}$ ); the xylotomical description is appropriate, in order to identify the unknown structure.

The pith - is not present in our sections because the axial part of the stem is absent in our fragmentary samples.

The cylindrical vascular system - in cross section, appears to consist of some alternate growth rings of secondary xylem and phloem, which indicate a polyxylic structure, traversed by numerous thin secondary rays (Fig. 8a). The wide multiseriate primary medullary rays appear only locally, in contact with the xylem of growth ring (see Fig. 8b). Through the xylem and phloem cells, obvious idioblasts appear, carrying mucilages or crystals often grouped as druses (Fig. 8d-f). The cambium cells are difficult to recognize. The xylem has rectangular to square tracheids ( $\mathrm{ra} / \mathrm{tg}$ diameters of 18-50/20-45 $\mu \mathrm{m}$ ), with rounded corners, with often slightly wavy walls, 3-6 $\mu \mathrm{m}$ as a double wall. On the radial walls, the tracheids show uni- to biseriate bordered pits, rounded or hexagonal, of 6-8 $\mu \mathrm{m}$, with round to elliptic apertures and are contiguous and flattened (Fig. 8i), usually alternate, where they are biseriate. Perforations were not seen. The tangential walls are not pitted. The phloem appears as parenchymal cells, with secretory idioblasts and sclerenchymal cells often with large crystals, or druses (Fig. 8d-e). At the border with the pith area, mucilaginous canals appear, lined by rows of epithelial cells.

The rays - in cross- and tangential sections the secondary rays appear numerous and thin, giving a manoxylic appearance to the structure. The primary rays were not observed; but they do appear in cross-section, in contact with xylem (see Fig. 8b). The secondary rays are usually uniseriate, very numerous and are composed of parenchymal cells, and few secretory idioblasts, so that the rays are heterogeneous (Fig.8g). The ray cells have rounded to rectangular outlines, the idioblasts are similar, or slightly elongate and, in radial view, are all procumbent. The cross-fields show 2-6 oculipores, in one or two superposed rows and are slightly alternately arranged. 

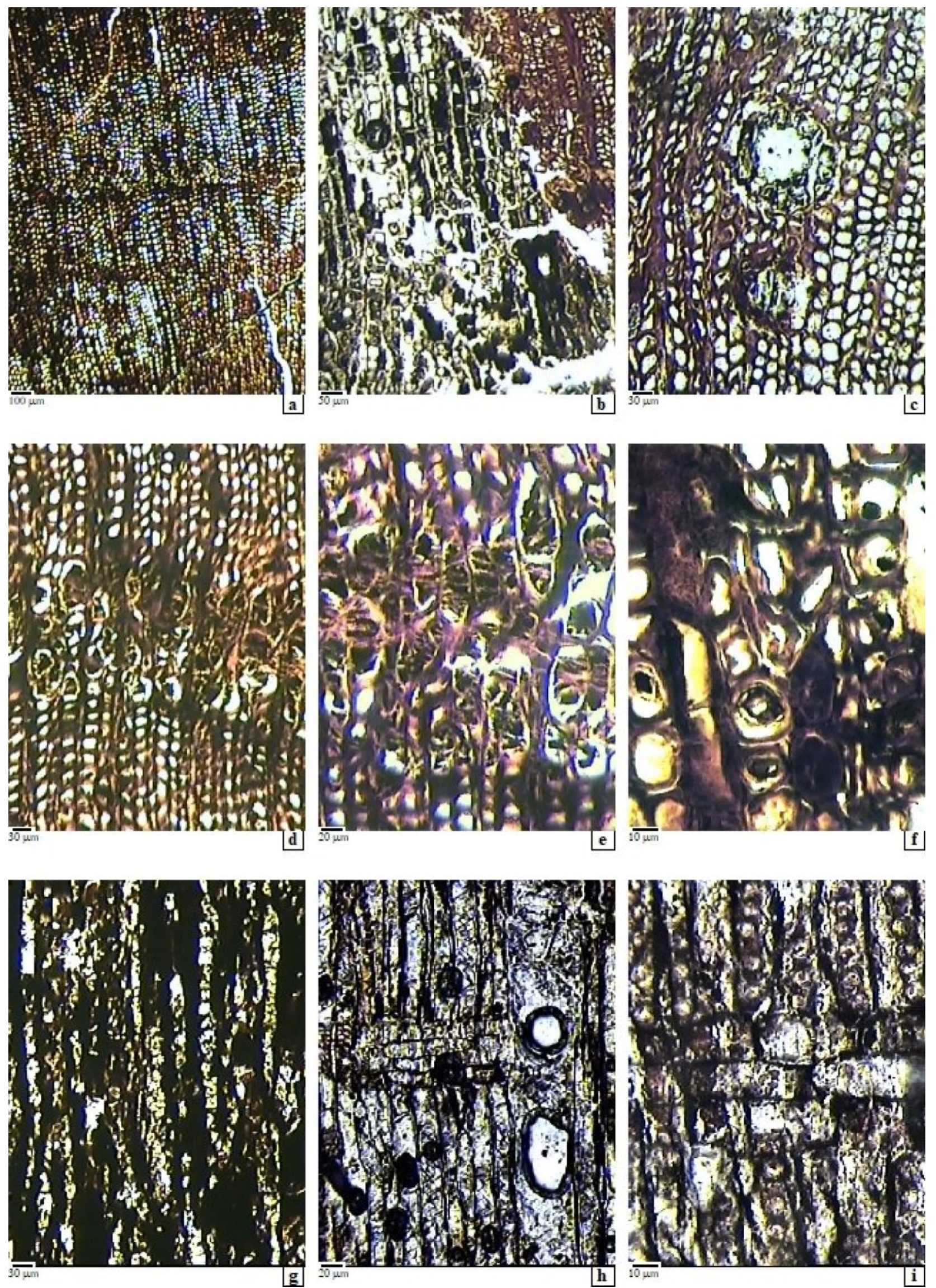

Fig. 8 Bucklandia sp. B - inventory no. 27676 and 27677 (field no. 1037 a-f, 1038g-i).

a-f: Cross section - b: - tracheids polygonal with rounded corners, and linear rays; primary ray in contact with xylem; c: - mucilaginous canals lined by secretory epithelial cells; d-e: - phloem cells with idioblasts bearing mucillages; f: - or crystals (f); g: Tangential section - uniseriate rays with biseriate storeys with polygonal ray-cells; unpitted tracheids; h-i: Radial section - mucilaginous canal (h); araucarian radial pitting on tracheids with uniseriate hexagonal pits (i), cross-fields with 2-3 superposed rows of hexagonal pits $(\mathbf{h}-\mathbf{i})$ 
Axial canals - appear at the border with the pith area, as large mucilaginous canals, with diameters of 360-930 $\mu \mathrm{m}$, lined by secretory epithelial cells (Fig. 8c, h).

\section{Afinities and discussion}

Having a cycadeoid stem structure, indicated by the presence of idioblasts with druses and of mucilaginous canals, we searched also for other xylotomical details, but the absence of scalariform thickenings on tracheids makes it different from the above-described form, and indicated a resemblance to a type close to the current Cycas (see Greguss, 1968).

In the Early Jurassic flora from Holbav, species of Nilssonia, Paracycas, Ctenis, Ptilophyllum, Pterophyllum appear, in addition to forms of Zamites-group (see Dragastan and Popa, 1997; Popa, 1997, 1998, 2000a, b).

Comparing to wood description of Zamuneria amyla (see Martinez et al., 2017) and, also, their identification key, we observed that our studied specimens indicate a columnar polyxylic stem, with several growth rings in the cylindrical vascular system, and with idioblasts and mucilaginous canals, similar to the genus Bucklandia Bosse, 1953, which is a stem of Williamsonia Caruthers, as it was described by Stockey and Rothwell (2003).

Our specimens have a structure similar to a Jurassic stem described by Zhang et al. (2012) as Sinocycadoxylon, which is also characterized by a polyxylic vascular cylinder with centrifugal rings of secondary xylem and araucarioid radial pitting on the tracheids.

Also, Iamandei et al. (2003) studied a fragmentary fossil wood from the Upper Jurassic of Hăghimaş Mts., Eastern Carpathians, which is identified as Cycadoxylon sp., which has a xylotomy very similar to our studied specimens.

Thus, the studied specimens show details that indicate a columnar form of Cycas-type (see Greguss, 1968), as is discussed above, so we assign them to Bucklandia sp. B, clearly different from the form described above.

\section{CONCLUSIONS}

The petrified woods found in the Holbav and Cristian areas, in the Braşov region, constitute the most significant collection of Early Jurassic lignoflora in the Romanian Carpathians, and the present study represents an important advance in the knowledge of the Mesozoic flora in the Carpathian area.

In the first part of our study (Iamandei et al., 2018), five species were taxonomically identified and described: Agathoxylon holbavicum Iamandei, Iamandei and Grădinaru, 2018, Brachyoxylon holbavicum Iamandei, Iamandei and Grădinaru, 2018, Brachyoxylon cristianicum Iamandei, Iamandei and Grădinaru, 2018, Protophyllocladoxylon holbavicum Iamandei, Iamandei and Grădinaru, 2018, and Palaeoginkgoxylon sp.

In the second part of our study, besides Brachyoxylon wood-types and of Palaeoginkgoxylon, already described in the first part, there are described two "cupressaceous" wood types, as species of Protocupressinoxylon and of
Protojuniperoxylon, the last one as a new species. In addition, two Bennettitalean forms were described, as members of Buklandia genus, which represents a novelty for the studied region. The list of the new identifications includes the following taxa:

\section{Order Pinales}

- Protocupressinoxylon dragastanii Iamandei and Iamandei, 2000

- Protojuniperoxylon holbavicum Iamandei, Iamandei and Grădinaru, sp. nov.

- Brachyoxylon holbavicum Iamandei, Iamandei and Grădinaru, 2018

- Brachyoxylon cristianicum Iamandei, Iamandei and Grădinaru, 2018

Order Ginkgoales

- Palaeoginkgoxylon sp.

Order Bennettitales

- Bucklandia sp. A

- Bucklandia sp. B

The present study of the fossil petrified woods material from the Lower Jurassic sedimentary deposits in the Holbav and Cristian areas significantly improves the palaeobiogeographic, palaeoenvironmental, palaeoecologic and palaeoclimatic reconstructions, not only in the Romanian Carpathians, but also at the continental scale.

The paleo-latitude of the South Carpathians during the Late Jurassic was about $18^{\circ} \mathrm{N}$, from palaeomagnetic data given in 1996 by Hambach et al. (fide Panaiotu, 1998). Since the latitude of the Tropic, during that time, was about $23^{\circ} 26^{\prime} 22^{\prime \prime}$ North, it is obvious that there was a tropical paleoclimate in the studied area, located in the Tethys Realm (see Lawver et al., 2015).

This was the optimal environment for the so-called tropical plants such as the Bennettitales were during the Mesophytic, but this does not mean that all the plants from the Tethys Realm were of 'tropical' type. According to Czier (2017), the Romanian Bennettitales that mainly represent a European autochthonous group, are indicators of warm environment, especially owing to the hypodermis structure and physiology of their leaves, and of the structure of their cuticles. However, other plants, like many allochthon pteridophytes, are present also in Eastern and Western 'temperate' regions (e.g. Clathropteris, of which the global migration pattern suggests North American origin).

\section{ACKNOWLEDGEMENTS}

Many thanks to reviewers for their important help to improve this paper, especially to Dr. Zoltán Czier (Hungary, Independent Senior Researcher), who made important observations on systematics and references. We are very grateful to Prof. Stephen Kershaw, of Brunel University London, for useful observations and for improving the English style of our manuscript. 


\section{REFERENCES}

Akkemik, Ü., 2021. A new species of Juniperoxylon from the Early Miocene of Northwestern Turkey. Acta Palaeontologica Romaniae, 17(1): 15-26. https://doi.org/10.35463/j.apr.2021.01.02

Alvin, K.L., 1982. Cheirolepidiaceae: Biology, structure and paleoecology. Review of Palaeobotany and Palynology, 37: 71-98.

Alvin, K.L., Fraser, C.J. and Spicer, R.A., 1981. Anatomy and paleoecology of Pseudofrenelopsis and associated conifers in the English Wealden. Palaeontology, 24: 759-778.

Andrews, H.N., Jr. 1955. Index of generic names of fossil plants, 1820-1950. [U.S.] Geological Survey Bulletin, 1013: 1-262.

Antonescu, E., 1973. Quelques données sur la palynologie du Lias sous faciès de Gresten de Roumanie. Palynology of Mesophyte. Proceedings of the 3rd International Palynological Conference, Nauka, Moskow: 13-17.

Bamford, M.K. and Philippe, M., 2001. Jurassic-Early Cretaceous Gondwanan homoxylous wood: a nomenclatural revision of the genera with taxonomic notes. Review of Palaeobotany and Palynology, 113: 287297.

Bamford, M.K., Philippe, M. and Thévenard, F., 2016. Long overdue extinction of the Protopinaceae. Review of Palaeobotany and Palynology, 234: 25-30.

Barbacka, M., Bodor, E., Jarzynka, A., Kustatscher, E., Pacyna, G., Popa, M.E, Scanu, G. G., Thevenard, F. and Ziaja, J., 2014. European Jurassic floras: statistics and palaeoenvironmental proxies. Acta Palaeobotanica, 54: 173-195.

Berry, E.W., 1916. The geological history of Gymnosperms. The Plant World, 19(2): 27-41. Published by: Wiley on behalf of the Ecological Society of America.

Bessey, C.E., 1907. A synopsis of plant phyla. University Studies of the University of Nebraska, 7: 275-373.

Blokhina, N.I., 1975. New species of conifers from the Jurassic of North Siberia (Fossil woods). Proceedings of Institute of Biology and Pedology, Vladivostok, n. sr., 27(130): 47-54. [in Russian]

Bodnar, J., Escapa, I., Cúneo, N.R., Gnaedinger, S., 2013. First record of conifer wood from the Canadon Asfalto Formation (Early-Middle Jurassic), Chubut Province, Argentina. Ameghiniana, 50: 227-239.

Bodnar, J., 2017. (2575) Proposal to conserve the name Protocupressinoxylon with a conserved type against Protobrachyoxylon(fossil plants). Taxon (Journal of IAPT), 66(6): 1480-1481. https://doi.org/10.12705/666.25

Bodnar, J. andArtabe, A.E., 2007. Estudio sistemático y paleodendrológico del leño de una Cupressaceae triásica de la Formación Ischigualasto, provincia de San Juan, Argentina. Ameghiniana, 44: 303-319.
Bonetti, M.I.R., 1966. Protojuniperoxylon ischigualastensis sp. nov. del Triásico de Ischigualasto (San Juan). Ameghiniana, 4: 211-218.

Bosse, M.N. 1953. Bucklandia sahnii sp. nov. from the Jurassic of the Rajmahal Hills, Bihar. Palaeobotanist, 2: 41-50.

Boureau, E. and Serra, C., 1961. Sur les structures normales et traumatiques d'un bois mésozoïque du Cambodge, le Brachyoxylon saurinii, n.sp. Revue générale de botanique, 68: 373-393.

Brongniart, A., 1828. Prodrome d'une histoire des végétaux fossils, pp. 1-223; Paris.

Carruthers Esq. Wm, F.L.S., F. G.S., 1870. XVIII. On Fossil Cycadean Stems from the Secondary Rocks of Britain. Transactions of the Linnean Society of London. 26(4): 675-708. https://doi.org/10.1111/j.10963642.1870.tb00201.x

Cevallos-Ferriz, S.R.S., 1992. Tres Maderas de Gimnospermas Cretacicas del Norte de Mexico. Anales del Instituto de Biologia Universidad Nacional Autonoma de Mexico, Serie Botanica, 63(2): 111-137.

Christenhusz, M.J.M., Reveal, J.L., Farjon, A., Gardner, M.F., Mill, R.R. and Chase, M.W., 2011. A new classification and linear sequence of extant gymnosperms. Phytotaxa, 19: 55-70.

Cobos, A.S., 1956. Nuevos géneros y especies de Eucnemidae (Insecta, Coleoptera) de la fauna neotropical. Bulletin del'Institut Royal des Sciences Naturelles de Belgique, 32 (no.41): 1-16.

Correa, G., Bodnar, J., Colombi, C., and Paula Santi Malnis, P.S., Praderio, A., Martínez, R., Apaldetti, C., Fernández, E., Abelín, D. and Alcober, O., 2019. Systematics and taphonomy of fossil woods from a new locality in the Upper Triassic Carrizal Formation of the El Gigantillo area (Marayes-El Carrizal Basin), San Juan, Argentina". Journal of South American Earth Sciences, 90: 94-106. https://doi.org/10.1016/j.jsames.2018.11.027

Creber, G.T., 1972. Gymnospermous wood from the Kimmeridgian of East Sutherland and from the Sandringham Sands of Norfolk. Palaeontology, 15(4): 655-661.

Czier, Z., 1994. A Körös-vidék és a Bánság liász flórája. Dr. Univ. doktori disszertáció. 229 p. (vol. 1), 211 p. (vol.2), Budapest (Eötvös Loránd Tudományegyetem, Természettudományi Kar).

Czier, Z., 1998. Ginkgo foliage from the Jurassic of the Carpathian Basin. Palaeontology, 41 (2): 349-381.

Czier, Z., 1999. Biostratigraphy of the Lower Jurassic from Romania, based on the macroflora fossil record. Nymphaea, Folia naturae Bihariae, 27: 43-58.

Czier, Z., 2000. Macroflora liasică din România, cu privire specială asupra Pădurii Craiului. 260 p., Oradea (Editura Imprimeriei de Vest).

Czier, Z., 2001. Rezumatul tezei de doctorat „Flora liasică din Crişana şi Banat". (Universitatea Eötvös Loránd - Budapesta, 1994). Nymphaea, Folia naturae Bihariae, 28: 27-46. 
Czier, Z., 2005. Plante fosile din colecţia Muzeului Țării Crişurilor, propuse pentru categoria tezaur. Nymphaea, Folia naturae Bihariae, 31: 133-155.

Czier, Z., 2008. Banatozamites remotus Czier sp. nov. (Cycadeoidales) from the Lower Jurassic of Anina, Romania. Nymphaea, Folia naturae Bihariae, 35: 526.

Czier, Z., 2009. Banatozamites calvus Czier sp. nov. and Bucklandia aninaensis Czier sp. nov. from the Lower Jurassic of Anina, Romania. Nymphaea, Folia naturae Bihariae, 36: 5-26.

Czier, Z., 2016a. The Bennettitalen genus Pterophyllum in the fossil flora of Romania, and the global phytostratigraphic-paleophytogeographic context. Vestnik TvGU, Seriya Biologiya i Ekologiya, 3: 133-184.

Czier, Z., 2016b. Probleme de stratigrafie cu privire la depozitele continentale ale Jurasicului inferior din România. In: Moisa, G., Goman, I., Șipoș, S. (coord.), Omagiu Chiriac Aurel. Fragmentarium, studii interdisciplinare: 538-573, Oradea (Editura Muzeului Țării Crișurilor).

Czier, Z., 2016c. European Paleofloristic Affinities of the Romanian Jurassic Macroflora. Nymphaea, Folia naturae Bihariae, 43: 13-66.

Czier, Z., 2018. The Genus Zamites Brongniart 1828 emend. Harris 1969 (Bennettitales) in the fossil flora of Romania. Nymphaea Folia naturae Bihariae, 45: 5 -34 .

Dragastan, O.N. and Popa, M.E., 1997. Early Jurassic Phytostratigraphy of the Holbav Formation, Getic Nappe, Braşov County. Revue Roumaine de Géologie, 41: 51-60.

Doweld, A.B., 2012. (2099) Proposal to conserve the name Bucklandia Brongn. against Bucklandia Sternb. and Conites (fossil Gymnospermae, Cycadeoideopsida). Taxon, 61(5): 1131-1132

Doweld, A.B., 2020. The controversial nomenclature of the fossil plant names Cheirolepis, Cheirolepidium and Hirmeriella (Cheirolepidaceae / Cheirolepidiaceae / Hirmeriellaceae). 69(5): 1092-1098.

Eckhold, W., 1921. Die Hoftüpfel bei rezenten und fossilen Koniferen. [PhD Thesis] Breslau Schlesische Fridrich-Wilhelms Universitat (Univ. of Wroclaw Poland)

Eckhold, W., 1922. Die Hoftüpfel bei rezenten und fossilen Coniferen. Jahrbuch Königliche Preussische Geologische Landesansalt, 42: 472-505.

Engler, H.G.A., 1892. Syllabus der Vorlesungenüberspecielle und medicinisch-pharmaceutischen Botanik. Eine Uebersichtüber das gesammte Pflanzen system mit Berücksichtigung der Medicinal-und Nutzpflanzen (1st ed.). Berlin: Verlag Gebrüder Borntraeger, 233pages.

Engler, H.G.A. and Prantl, K.A.E., 1897. Die Natürlichen Pflanzen familien nebstihren Gattungen und wichtigeren Arten. Nachträge, I-IV: Unterabteilung Gymnospermae [II(1)] p. 6. Leipzig: W. Engelmann Verlag.
Feng, Z., Wang, J. and Rößler, R., 2010. Palaeoginkgoxylon zhoui, a new ginkgophyte wood from the Guadalupian (Permian) of China and its evolutionary implications. Review of Palaeobotany and Palynology, 162: 146-158.

Fossil works - online. Gateway to the Paleobiology Database - Fossilworks: Cheirolepidiaceae.

Francis, J.E., 1983. The dominant conifer of the Jurassic Purbeck Formation, England. Palaeontology, 26: 277294.

Garcia, J.-P., Philippe, M. and Gaumet, F., 1998. Fossil wood in Middle-Upper Jurassic marine sedimentary cycles of France: relations with climate, sea-level dynamics, and carbonate-platform environments. Palaeogeography, Palaeoclimatology, Palaeoecology, 141(3-4): 199-214.

GBIF online - Buckia vaucheri (mindat.org); Buckia vaucheri (Lesq.) D.Rios, M.T.Gallego and J.Guerra (gbif.org)

Givulescu, R., 1991a. Zamites vachrameevii Doludenko 1969 in dem Unteren Lias, Rumänien. Acta Palaeobotanica, 31(1-2): 17-21.

Givulescu, R., Czier, Z., 1990. Neue Untersuchungen über die Floren des Unteren Lias (Rumänien). Documenta naturae, 59: 8-19.

Gorozhankin, I.N., 1904. Gingkoales. (Published in: Lektsii po Morfologii I Sistematike Archegonialnykh Rastenij. II. Pteridophyta I. Archispermae. Moscow: A.I. Mamontov) (Russian scientific publication usually cited as: Lekts. Morf. Sist. Archegon.), 73: p.93. [in Russian]

Greguss, P., 1961. Permische fossile Holzer aus Ungarn. Palaeontographica, Abt. B, Palaophytologia, 109: 131-146.

Greguss, 1968. Xylotomy of the living Cycads, with a description of their leaves and epidermis. 1-260 pages, Akadémiai Kiado.

Hambach, U., Panaiotu, C. and Panaiotu, C. E., 1996. Gondwana origin of the Tisza-Dacia unit? Arguments from paleomagnetism. PANCARDI Workshop 1996 (abstract). Mitteilungen der Gesellschaft der Geologie und Bergbaustudenten Österreichs, 41: 101-148.

Harris, T.M., 1979. The Yorkshire Jurassic Flora. 5. Coniferales. British Museum Natural History, London, $167 \mathrm{pp}$.

Herbst, R. and Crisafulli, A., 2016. La flora triásica del grupo El Tranquilo, provincia de Santa Cruz (Patagonia): leños fósiles. Ameghiniana, 48(3): 78-102.

Hickey, L.J., Hu, S. and Skinner, B.J., 2011. A New genus of silicified conifer wood from the Late Triassic of Connecticut. American Journal of Science, 311(7): 608-631.

Holden, R., 1913. Contributions to the Anatomy of Mesozoic Conifers. 1. Jurassic coniferous woods from Yorkshire. Annals of Botany, 27(5): 33-549.

Hollick, A. and Jeffrey, E.C., 1909. Studies of coniferous Cretaceous remains from Kreischerville (New-York). 
Memoirs of the New York Botanical Garden, 3: 1137.

Iamandei E. and Iamandei S., 2000. Bois fossiles de Coniféres dans l'Aptien de Dobroudja de Sud, Romania. Acta Palaeontologica Romaniae, 2(1999): 191-199.

Iamandei, S., Iamandei, E. and Ţibuleac, P., 2001. Fossil Wood from Coal-layer "B" of Volhinian Formation in Leucuşeşti - Fălticeni area. Analele Ştiinţifice ale Universităţii "Al.I.Cuza" (s.n.), Geologie, 47: 211218.

Iamandei E., Iamandei S. and Grinea, D., 2003, Cycadoxylon sp., a Fossil Wood from Upper Jurassic of Hăghimaş. Revue roumaine de Géologie, 47, 43-53.

Iamandei, E. and Iamandei, S., 2005. Early Cretaceous protopinaceous fossil wood from South Dobrogea, Romania. Acta Palaeontologica Romaniae, 5: 231247.

Iamandei, S., Iamandei, E. and Grădinaru, E., 2018. Contributions to the study of the Early Jurassic Petrified Forest of Holbav and Cristian areas (Brașov region, South Carpathians, Romania). $1^{\text {st }}$ part. Acta Palaeontologica Romaniae, 14(2): 3-34.

Iijima, A., Kakuwa, Y. and Matsuda, H., 1989. Silicified Wood from the Adoyama Chert, Kuzuh, Central Honshu, and Its Bearing on Compaction and Depositional Environment of Radiolarian Bedded Chert. In: Hein J.R., Obradović J. (eds.), Siliceous Deposits of the Tethys and Pacific Regions. Springer, New York.

IAWA Committee, 2004. IAWA list of microscopic features for softwood identification. Eds. Baas, P. et al. for International Association of Wood Anatomists, in IAWA Journal, 25: 1-70.

Jogmans, W.J. and Djijkstra, S.J., 1974. FossiliumCatalogus II: Plantae. Pars. 85, Gymnospermae. (Gingkophyta et Coniferae) VII. Ed. S.J. Dijkstra.Online: Fossilium Catalogus.

Kräusel, R., 1917. Die Bedeutung der Anatomielebender und fossiler Hölzer für die Phylogenie der Koniferen. Naturwissenschaften Wochenschrift, 16: 305-311.

Kräusel, R., 1949. Die fossilen Koniferen-Hölzer (Unter Ausschluß von Araucarioxylon Kraus). II: Kritische Untersuchungenzur Diagnostik lebender und fossiler Koniferen-Hölzer. Palaeontographica, Abt. B, 89: 83203.

Lawver, L.A., Dalziel, I.W.D., Norton, I.O., Gahagan, L.M. and Davis, J., 2015. The PLATES 2014. Atlas of Plate Reconstructions (550 Ma to Present Day), PLATES Progress Report No. 374-0215. University of Texas Technical Report No. 201, 220pp.

Link, J.H.F., 1829. Handbuchzur Erkennung der nutzbarsten und am häufigsten vorkommen den Gewächse. Berlin: Haude und Spener.

Lu Y., Ran J-H., Guo D-M., Yang Z-Y. and Wang X-Q., 2014. Phylogeny and Divergence Times of Gymnosperms Inferred from Single - Copy Nuclear Genes. PLoS ONE, 9(9): 1-15.

https://doi.org/10.1371/journal.pone.0107679
Martínez L.C.A. and Lutz, A.I., 2007. Especies nuevas de Baieroxylon Greguss y Circoporoxylon Kräusel en las formaciones Rayoso y Huincul (Cretácico), provincia del Neuquén, Argentina. Ameghiniana, 44(3): 537546.

Martínez, L., Artabe, A. and Bodnar, J. 2012. A new Cycad stem from the Cretaceous in Argentina and its phylogenetic relationships with other Cycadales. Botanical Journal of the Linnean Society, 170: 436-458.

Martínez, L.C.A., Iglesias, A., Artabe A.E., Varela A.N. and Apesteguía, S., 2017. A new Encephalarteae trunk (Cycadales) from the Cretaceous of Patagonia (Mata Amarilla Formation, Austral Basin), Argentina. Cretaceous Research, 72: 81-94

http://dx.doi.org/10.1016/j.

McLoughlin, S. and Strullu-Derrien, C. 2016. Biota and palaeoenvironment of a high middle-latitude Late Triassic peat-forming ecosystem from Hopen, Svalbard archipelago. Geological Society, London, Special Publications, 434: 87-112.

https://doi.org/10.1144/SP434.4

Müller-Stoll, W.R. and Schultze-Motel, J., 1989. Gymnospermen-Hölzer des Deutschen Jura. Teil 2: Die Protopinoiden Hölzer. Zeitschrift der Deutschen Geologischen Gesellschaft, 140: 53-71.

IFPNI - The International Fossil Plant Names Index -; www.fossilplants.info/genus.htm?id=D46FC51A7AEB-421E-AF52-1A3F90515E43. (05. 20. 2021)

Meyen, S. V. 1984. Basic features of gymnosperm systematics and phylogeny as evidenced by the fossil record. Botanical Review, 50: 1-111.

Müller-Stoll, W.R. and Schultze-Motel, J., 1989. Gymnospermen-Hölzer des Deutschen Jura. Teil 2: Die Protopinoiden Hölzer. Zeitschrift der Deutschen Geologischen Gesellschaft, 140: 53-71.

Nathorst, A.G., 1913. How are the names Williamsonia and Wielandiella to be used? Geologiska Föreningeni Stockholm Förhandlingar, 35:6, 361-366. https://doi.org/10.1080/11035891309443477

Panaiotu, C., 1998. Paleomagnetic constrains on the geodynamic history of Romania, In: D. Ioane (ed.): Monograph of Southern Carpathians, Reports on Geodesy, 7(37).

Philippe, M., 1993. Nomenclature générique des trachéidoxyles mésozoïques à champs araucarioïdes. Taxon, 42: 74-80.

Philippe, M., 1995. Bois fossils du Jurassique de Franche-Comté (NE-France). Palaeontographica Abt. B, 236: 45-103.

Philippe, M., 2002. Reappraisal of five genera designed for fossil coniferous woods by early American wood anatomists. IAWA Journal, 23: 319-326.

Philippe, M. and Bamford, M.K., 2008. A key to morphogenera used for Mesozoic conifer-like woods. Review of Palaeobotany and Palynology, 148: 184-207.

Philippe, M., Bamford, M., McLoughlin, S., Alves, L.S.R., Falcon Lang, H.J., Gnaedinger, S., Ottone, E.G., Pole, M., Rajanikanthi, A., Shoemaker, R.E., 
Torres, T. and Zamuner, A., 2004. Biogeographic analysis of Jurassic-Early Cretaceous wood assemblages from Gondwana. Review of Palaeobotany and Palynology, 129: 141-173.

Philippe, M., Cuny, G., Bamford, M., Jaillard, E. and Barale, 2011. Révision de Brachyoxylon rotnaense Mathiesen, description de $B$. serrae n.sp. et conséquences pour la stratigraphie du Crétacé inférieur d'Asie du Sud-Est. Geodiversitas, 33: 25-32.

Phillips, E.W.J., 1941. The identification of coniferous woods by their microscopic structure. Journal of the Linnean Society of London, Botany, 52: 259-320.

Popa, M.E., 1997. Corystospermal pteridosperms in the Liassic continental deposits of Romania. Acta Palaeontologica Romaniae, 1: 81-87.

Popa, M.E., 1998. The Liassic continental flora of Romania: Systematics, Stratigraphy and Paleoecology. Acta Botanica Horti Bucurestensis: 177-184.

Popa, M.E., 2000a. Aspects of Romanian Early Jurassic palaeobotany and palynology. Part III. Phytostratigraphy of the Getic Nappe. Acta Palaeontologica Romaniae, 2: 377-386.

Popa, M.E., 2000b. Early Jurassic land flora of the Getic Nappe. PhD thesis, University of Bucharest, 258 pp, Bucharest.

Popa, M.E. and van Konijnenburg-van Cittert, J.H.A., 1999. Aspects of Romanian Early Jurassic palaeobotany and palynology. Part I. In situ spores from the Getic Nappe, Banat, Romania. Acta Palaeobotanica, Suppliment 2: 181-193. Proceedings of $5^{\text {th }}$ EPPC. W. Szafer Institute of Botany, Krakow.

Popa, M.E. and van Konijnenburg-van Cittert, J.H.A., 2006. Aspects of Romanian Early - Middle Jurassic palaeobotany and palynology. Part VII. Successions and floras. Progress in Natural Sciences, 16 (Special Issue): 203-212.

Reveal, J.L., 1996. Newly required suprageneric names in Magnoliophyta. Phytologia, 79: 68-76.

Roggeveen, P.M., 1932. Mesozoisches Koniferenholz (Protocupressinoxylon malayense n.s.) von der Insel Soegi im Riouw-Archipel. Niederländisch Ost Indien. Proceedings of the Section of Science, Koninklijke (Nederlandse) Akademie van Wetenschappente Amsterdam, 35: 580-584.

Ruffinatto, F., Crivellaro, A. and Wiedenhoeft, A.C., 2015. Review of macroscopic features for hardwood and softwood identification and a proposal for a new character list. IAWA Journal, 36(2): 208-241.

Ruiz, D.P. and Bodnar, J., 2019. The oldest record of Juniperoxylon, a cupressaceous fossil wood from the Middle Triassic of Argentina. Acta Palaeontologica Polonica, 64(3): 481-488.

Saiki, K. and Yoshida, Y., 1999. A New Bennettitalean Trunk with Unilacunar Five-Trace Nodal Structure from the Upper Cretaceous of Hokkaido, Japan. American Journal of Botany, 86(3): 326-332.

https://doi.org/10.2307/2656754;

https://www.jstor.org/stable/2656754
Săndulescu, M., Antonescu Em., Popa El., Tomescu, C., 1984. Cercetări pentru reevaluarea perspectivelor de cărbuni liasici din Țara Bîrsei. Tema 1.1.b. Raport Arhiva Institutului de Geologie și Geofizică. [in Romanian].

Schultze-Motel, J., 1960. Gymnospermen Holzer aus den Oberen Kreide von Quedlinburg. Paläontologische Zeitschrift, 34: 1-15.

Scott, D.H. 1923. Studies in fossil botany. Vol. 2, $3^{\text {rd }}$. Ed. A. and C. Black, London.

Selling, O.H., 1951. On Protojuniperoxylon arcticum. Journal of Paleontology, 25(4): 538-539.

Sharma, B. D. 1967. Investigations on the Jurassic flora of Rajmahal Hills, India. 4. On a new species of Indian Bucklandia, B. guptai, with remarks on B. sahnii of Bose. Ameghiniana, 4: 35-46.

Sharma, B. D. 1969. Bucklandia dichotoma sp. nov. from the Middle Jurassic of Rajmahal Hills, India. Ameghiniana, 6: 303-308.

Sharma, B.D., 1973. Anatomy of petrified rachises collected from the Jurassic of Amarjola in the Rajmahal Hills, India. The Proceedings of the Linnean Society of NSW, 98:43-49.

Sharma, B. D. 1991. Indian Williamsoniaceae - an overview. Paleobotanist, 4: 260-265

Stopes, M., 1915. Catalogue of the Mesozoic plants in the British Museum - The Cretaceous flora, Part 2, Lower Greensand (Aptian) plants of Britain: London, British Museum (Natural History), 360 p.

Stockey, R. and Rothwell, G.W., 2003. Anatomically Preserved Williamsonia (Williamsoniaceae): Evidence for Bennettitalean Reproduction in the Late Cretaceous of Western North America. International Journal of Plant Sciences 164(2):251-262. https://doi.org/10.1086/346166

Strullu-Derrien, C., McLoughlin, S., Philippe, M., Mørk, A. and Strullu, D.G., 2012. Arthropod interactions with bennettitalean roots in a Triassic permineralized peat from Hopen, Svalbard Archipelago (Arctic). Palaeogeography Palaeoclimatology Palaeoecology 348349: 45-58.

https://doi.org/10.1016/j.palaeo.2012.06.006

Süss, H., 2003. Zwei neue fossile Hölzer der Morphogattung Ginkgoxylon Saporta emend. Süss aus Tertiären Schichten der Insel Lesbos, Griechenland, miteiner Übersichtüber Fossilien mit ginkgoaler Holzstruktur. Feddes Repertorium, 114(5-6): 301-319.

DOI: 10.1002/fedr.200311001 [in German]

Süss, H., Rößler, R., Boppré, M. and Fischer, O.W., 2009. Drei neue fossile Hölzer der Morphogattung Primoginkgoxylon gen. nov. aus der Trias von Kenia. Fedes Repertorium, 120(5-6): 273-292; https://doi.org/10.1002/fedr.200911108

Taylor, T.N., 1981. Paleobotany. An Introduction to Fossil Plant Biology. xiii + 589 pp. Publisher: McGrawHill. ISBN 0070629544. 
Taylor, T.N., Taylor, E. and Krings, M., 2009. Paleobotany. The Biology and Evolution of Fossil Plants. Edition: $2^{\text {nd }}, 1252$ p. Publisher: Academic Press / Elsevier. https://doi.org/10.2307/1223352

Turutanova-Ketova, A., 1963. Williamsoniaceae in Soviet Union. Trudy botaniki, Institut Akademii Nauka, SSSR, ser. 8, Paleobotanika, 4: 7-55, 12 figs. Pls. 1-7 [in Russian]

Vera, E.I. and Césari, S.N., 2012. Fossil woods (Coniferales) from the Baqueró Group (Aptian), Santa Cruz Province, Argentina. Anais da Academia Brasileira de Ciências (Annals of the Brazilian Academy of Sciences), 84(3): 617-625.

Vogellehner, D., 1967. Zur Anatomie und Phylogenie de Mesozoischer Gymnospermenhölzer, 7: Prodromus zueiner Monographie de Protopinaceae. I. Die Protopinoiden Hölzer des Trias. Palaeontographica Abt. B, 121(1-3): 30-51.

Vogellehner, D., 1968. Zur Anatomie und Phylogenie de Mesozoischer Gymnospermenhölzer, 7: Prodromus zu einer Monographie de Protopinaceae. II. Die Protopinoiden Hölzer des Jura. Palaeontographica Abt. B, Stuttgart, 124(4-6): 125-162.
Wang, S.J., Jiang, Y.F. and Qin, Y., 1994. A new petrified wood from Taiyuan Formation, Xuzhou coalfield, Jiangsu province. Acta Botanica Sinica, 36: 194-198.

Zhang, W., Li Y., Zheng, S.L., Li, N., Wang, Y.D., Yang, X.J., Yi, T.M., Yang, J.J. and Fu, X.P., 2006. Fossil woods of China (Chinese ed.). China Forestry Publishing House, Beijing, 1-356 p.

Zhang W., Yang X.-J., Fu X.-P., Zheng S.-L. and Wang Y.-D., 2012. A polyxylic cycad trunk from the Middle Jurassic of western Liaoning, China, and its evolutionary implications. Review of Palaeobotany and Palynology, 183: 50-60.

Zheng, S.L., Li, Y., Zhang, W., Li, N., Wang, Y.D., Yang, X.J., Yi, T.M., Yang, J.J. and Fu, X.P., 2008. Fossil woods of China (English edition). China Forestry, Beijing: 1-356. 